\title{
A Comparison of International and Domestic Sources of Global Governance Dynamics
}

\author{
THOMAS BERNAUER, ANNA KALBHENN, VALLY KOUBI AND \\ GABRIELE SPILKER*
}

Existing empirical models of international co-operation emphasize domestic determinants, although virtually all theories of international relations focus on interdependencies between countries. This article examines how much states' linkages with the international system, relative to domestic factors, such as income and democracy, influence the dynamics of global governance efforts. To this end, we study the ratification behaviour of 180 countries vis-à-vis 255 global environmental treaties. Except for integration into the world economy, which affects co-operative behaviour negatively, our results show that international factors have a stronger and more positive impact on cooperative behaviour than domestic factors. This implies that Galton's advice not to examine the effects of internal and external variables in isolation is also useful in the study of international politics.

In this article, we examine to what extent linkages between states and the international system and with each other influence international co-operation, relative to domestic factors such as income and democracy. Conventional wisdom among analysts of international affairs holds that foreign policy behaviour of countries, and by implication also international co-operation and global governance efforts, are influenced both by internal (domestic) and external (international) factors. Moreover, virtually all theories of international relations pay a great deal of attention to interdependencies among countries, and interdependent decision-making in particular. ${ }^{1}$

And yet, there is a surprising disconnect between this widely shared view and empirical models of international co-operation. Large- $N$ empirical models, in particular, emphasize domestic determinants. They pay only scant attention to how pre-existing linkages of a country with the international system more broadly affect co-operative behaviour in specific cases, and how one country's behaviour is affected by the behaviour of

* Bernauer, Kalbhenn and Spilker: Center for Comparative and International Studies (CIS) and Institute for Environmental Decisions (IED), ETH Zurich; Koubi: Department of Economics and Oeschger Center for Climate Change Research, University of Bern, and also CIS and IED, ETH Zurich (email: thbe0520@ethz.ch). Authorship is listed alphabetically and reflects equal contribution. The authors thank Xun Cao, Han Dorussen, Erik Gartzke, Martin Gassebner, Christopher Gelpi, Kristian Skrede Gleditsch, Bo Honoré, Simon Hug, Gyung-Ho Jeong, Patrick Kuhn, Vera Troeger, Johannes Urpelainen and the Journal's Editor Hugh Ward, as well as four anonymous reviewers, for helpful comments on earlier versions of this article. They are also very grateful to Ronald Mitchell for providing the data on environmental agreements and very much appreciate the knowledgeable research assistance given by Marianne Furrer. This article was written in the context of the National Center for Competence in Research (NCCR), 'Democracy in the 21st Century'. Supplementary material provided by the authors is to be found on the Journal's website at < journals.cambridge.org/jps $>$.

1 Robert Axelrod, The Complexity of Cooperation: Agent-based Models of Competition and Collaboration (Princeton, N.J.: Princeton University Press, 1997); Robert Keohane and Joseph Nye, Power and Interdependence (Boston, Mass.: Little, Brown, 1977). 
other countries. ${ }^{2}$ This article addresses this imbalance between theorizing on the implications of interdependence in the international system and the empirical analysis of international co-operation.

Empirically, we are interested in the factors that motivate countries to ratify international treaties. In particular, we study the effects of country-external and country-internal determinants of international co-operation side-by-side, thus viewing ratification behaviour through the lens of Galton's problem. ${ }^{3}$ We thereby focus on global environmental agreements, that is, agreements that are open to ratification by all countries globally. Environmental issues have over the past three decades moved from the realm of low politics into the mainstream of the global policy agenda. This development is, for example, reflected in the portfolios of virtually all institutional heavyweights in the international system - from the World Trade Organization and the World Bank to the OECD and the European Union. It is also reflected in increasing mass media attention to international environmental problems, such as climate change.

The international environmental politics literature has grown enormously, with ever more detailed and sophisticated case-study work illuminating the causes of environmental problems, and the determinants of success or failure in solving these problems. ${ }^{4}$ While the ( single or comparative, small- $N$ ) case-study work, which thus far dominates the field, is highly insightful and important, there is also a need for more macro-level, quantitative research that examines the 'large picture'.

International environmental treaties do not of themselves solve problems of environmental degradation..$^{5}$ But they are key elements in virtually all efforts to build international governance systems (regimes) for such purposes and are thus often a precondition for solving environmental problems. Only a very few studies have examined the factors that motivate countries to enter into legally binding environmental commitments at the international level. ${ }^{6}$ Most work of this kind concentrates on specific international agreements.

${ }^{2}$ Emilie M. Hafner-Burton, Jana von Stein and Erik Gartzke, 'International Organizations Count', Journal of Conflict Resolution, 52 (2008), 175-88.

3 Detlef Jahn, "Globalization as "Galton's Problem": The Missing Link in the Analysis of Diffusion Patterns in Welfare State Development', International Organization, 60 (2006), 401-31. In 1889, Sir Francis Galton argued that cultural similarities could be due not only to evolutionary development but also to common descent and borrowing. He also argued that explanations that did not take into account all these possibilities could arrive at false conclusions. In our case, these driving forces can be conceptualized in terms of country-internal characteristics and country-external factors.

${ }^{4}$ Ronald B. Mitchell, 'International Environment', in Thomas Risse, Beth Simmons and Walter Carlsnaes, eds, Handbook of International Relations (London: Sage, 2002), pp. 500-16.

${ }^{5}$ Peter M. Haas, Robert O. Keohane and Marc A. Levy, Institutions for the Earth: Sources of Effective International Environmental Protection (Cambridge, Mass.: MIT Press, 1993); Thomas Bernauer, 'The Effect of International Environmental Institutions: How We Might Learn More', International Organization, 49 (1995), 351-77; Tobias Siegfried and Thomas Bernauer, 'Estimating the Performance of International Regulatory Regimes: Methodology and Empirical Application to International Water Management in the Naryn / Syr Darya Basin', Water Resources Research, 43 (2007), 1-14; Oran Young, The Effectiveness of International Environmental Regimes: Causal Connections and Behavioral Mechanisms (Global Environmental Accord: Strategies for Sustainability and Institutional Innovation), (Cambridge, Mass.: MIT Press, 1999); Carsten Helm and Detlef Sprinz, 'Measuring the Effectiveness of International Environmental Regimes', Journal of Conflict Resolution, 44 (2000), 630-52; Ronald B. Mitchell, 'Regime Design Matters: Intentional Oil Pollution and Treaty Compliance', International Organization, 48 (1994), 425-58.

${ }^{6}$ David J. Frank, 'The Social Bases of Environmental Treaty Ratification, 1900-1990', Sociological Inquiry, 69 (1999), 523-50. Eric Neumayer, 'Does Trade Openness Promote Multilateral Environmental Cooperation?' World Economy, 25 (2002), 815-32; Eric Neumayer, 'Do Democracies Exhibit Stronger 
Von Stein studies the Framework Convention on Climate Change and the Kyoto Protocol and the challenge of designing mechanisms that 'deter defection without deterring participation'. ${ }^{7}$ She finds that with harder to meet obligations countries become more selective about ratification. Her results also suggest that flexibility mechanisms may to some extent help in addressing this dilemma, and that domestic and international networks have fostered ratification of the Framework Convention, but not the Kyoto Protocol.

Murdoch et al. study treaty participation as a two-stage game in which states first decide on whether to participate (ratification stage) and then they decide on their level of participation (implementation stage). ${ }^{8}$ They argue that a country's behaviour should differ between the ratification stage, when co-operation and binding commitments by others are important considerations, and the implementation stage, when strategic considerations regarding own efforts of compliance dominate. They test their argument with data on twenty-five countries that ratified the Helsinki Protocol (an agreement on air pollution in Europe). They find that reduced emission imports resulting from reductions abroad promote treaty ratification by the beneficiary country, whereas that very same explanatory variable also increases free-riding at the implementation stage - in the latter case, other countries' emission reductions substitute for one's own efforts beyond the mandated reductions.

Neumayer examines ratification behaviour with respect to several international environmental treaties, postulating that trade openness promotes multilateral environmental co-operation. ${ }^{9}$ He finds some, albeit weak, evidence in support of this hypothesis, suggesting that ratification depends on how the respective agreement affects specific interests in exporting countries. In a closely related paper, Neumayer studies whether democracies exhibit stronger international environmental commitment than non-democracies. ${ }^{10}$ Focusing on treaties for endangered species, biodiversity and ozone layer protection, he finds evidence that democracies join more multilateral environmental agreements and intergovernmental environmental organizations, and that they perform better with respect to reporting requirements under the Convention on International Trade in Endangered Species of Fauna and Flora. Neumayer concludes that 'a spread of democracy around the world will lead to enhanced environmental commitment worldwide'. ${ }^{11}$

Congleton and Fredriksson and Gaston examine the Montreal Protocol and the Framework Convention on Climate Change, respectively, and find that democracies are more likely to ratify these agreements. ${ }^{12}$ Similarly, Fredriksson and Ujhelyi observe that democracy

(F'note continued)

International Environmental Commitment? A Cross-Country Analysis', Journal of Peace Research, 39 (2002), 139-64; James C. Murdoch, Todd Sandler and Wim P.M. Vijverberg, 'The Participation Decision versus the Level of Participation in an Environmental Treaty: A Spatial Probit Analysis', Journal of Public Economics, 87 (2003), 337-62; Timmons J. Roberts, Bradley C. Parks and Alexis A. Vásquez, 'Who Ratifies Environmental Treaties and Why? Institutionalism, Structuralism and Participation by 192 Nations in 22 Treaties', Global Environmental Politics, 4 (2004), 22-64; Jana von Stein, 'The International Law and Politics of Climate Change', Journal of Conflict Resolution, 52 (2008), 243-68.

7 Von Stein, 'The International Law and Politics of Climate Change', p. 243.

8 Murdoch et al., 'The Participation Decision versus the Level of Participation in an Environmental Treaty'.

9 Neumayer, 'Does Trade Openness Promote Multilateral Environmental Cooperation?'

10 Neumayer, 'Do Democracies Exhibit Stronger International Environmental Commitment?'

11 Neumayer, 'Do Democracies Exhibit Stronger International Environmental Commitment?' p. 139.

12 Roger D. Congleton, 'Political Institutions and Pollution Control', Review of Economics and Statistics, 74 (1992), 412-21; Per G. Fredriksson and Noel Gaston, 'Ratification of the 1992 Climate Change Convention: What Determines Legislative Delay?', Public Choice, 104 (2000), 345-68. 
and environmental lobby groups have a positive effect on the ratification of international environmental agreements. ${ }^{13}$ In contrast to these studies, Murdoch et al., in their study on the Helsinki Protocol, find that democratic countries are less likely to ratify this treaty but more likely to make bigger efforts at the implementation stage. ${ }^{14}$ Zilbauer studies ratification delays in five environmental agreements as a function of democracy and presence of environmental lobby groups. ${ }^{15} \mathrm{He}$ finds that 'democracy as well as environmental pressure group strength tend to reduce ratification delay in four out of five agreements ... However, one treaty exhibits reverse effects, indicating that the relationship cannot be generalized on all international environmental problems alike'. ${ }^{16}$

Roberts et al. carry out a cross-sectional study of the determinants of ratification rates of twenty-two international environmental treaties by 177 countries during 1946-99. ${ }^{17}$ They find that most variance in environmental treaty ratifications is explained by 'disadvantaged insertion into the world economy' (defined in terms of a narrow export base), voice and accountability through domestic institutions and civil society pressure (number of nongovernmental organizations (NGOs) in the country) - all three variables having a positive effect. The authors conclude 'the number of NGOs in a nation appears virtually synonymous with its likelihood to participate in environmental treaties'. ${ }^{18}$ Similarly, Frank seeks to explain the number of international environmental treaties ratified by a country in four time-periods: $1900-45,1946-62,1963-72$ and $1973-90 .{ }^{19}$ He finds that the number of a country's linkages to world society (measured by membership in international non-governmental science and/or environmental associations) is the strongest predictor of ratification.

These studies of international environmental commitments offer important insights. But their findings leave room for further research. First, they are based on very small samples of international environmental treaties or individual treaties (partial exceptions are Roberts et al. and Frank). ${ }^{20}$ Secondly, their empirical design is (with the exception of von Stein and Zilbauer) ${ }^{21}$ cross-sectional and does not consider temporal dynamics. Thirdly, and most importantly for this article, the driving forces examined are largely domestic, whereas the recent literature on international co-operation suggests that co-operative behaviour vis-à-vis international governance systems is likely to be shaped also by pre-existing linkages of states with the international system and by how other states behave in the area of concern. ${ }^{22}$

${ }^{13}$ Per G. Fredriksson and Gergely Ujhelyi, 'Political Institutions, Interest groups, and the Ratification of International Environmental Agreements' (Houston, Texas: University of Houston, Department of Economics Working Paper, 2006).

${ }^{14}$ Murdoch et al., 'The Participation Decision versus the Level of Participation in an Environmental Treaty'.

${ }^{15}$ Matthias Zilbauer, 'Determinants of International Environmental Cooperation: Does ENDO Strength Foster a Country's International Environmental Commitment?' (unpublished manuscript, Konstanz: University of Konstanz, 2005).

${ }_{16}$ Zilbauer, 'Determinants of International Environmental Cooperation', p. 5.

17 Roberts et al., 'Who Ratifies Environmental Treaties and Why?'

18 Roberts et al., 'Who Ratifies Environmental Treaties and Why?' p. 39.

${ }^{19}$ Frank, 'The Social Bases of Environmental Treaty Ratification, 1900-1990'.

${ }^{20}$ Frank, 'The Social Bases of Environmental Treaty Ratification, 1900-1990'; Roberts et al., 'Who Ratifies Environmental Treaties and Why?'

${ }^{21}$ Von Stein, 'The International Law and Politics of Climate Change'; Zilbauer, 'Determinants of International Environmental Cooperation'.

${ }^{22}$ Detlef Jahn, 'The Politics of Climate Change' (paper presented at the ECPR conference, 2008, Rennes; Beth A. Simmons, Frank Dobbin and Geoffrey Garrett, 'Introduction: The International Diffusion of 
In this article, we add to the existing literature in several ways. First, unlike previous studies, our work examines the external and internal driving forces of international co-operation side-by-side and systematically compares their (relative) importance. Moreover, unlike previous studies, we examine the effects of two distinct types of external factors: political and economic integration into the international system broadly defined, and contingent behaviour. The latter illuminates the extent to which the ratification behaviour of any given country is affected by whether other countries or specific other countries ratify.

Secondly, we use a much larger sample than previous studies to test our hypotheses. Our dataset covers global environmental treaty ratifications in the time-period 1950-2000 (approximately 180 countries and 255 global environmental treaties over fifty years).

Thirdly, we use a novel empirical research design - with treaty-country pairs over time as the unit of observation. This research design permits analysis of the spatial and temporal evolution of international environmental co-operation, which is particularly important when analysing contingent (interdependent) ratification behaviour of countries. The data analysis relies on a binary-times-series-cross-sectional (BTSCS) approach as proposed by Carter and Signorino. ${ }^{23}$

With the exception of integration into the world economy, which affects co-operative behaviour negatively, the results show that international factors have a positive and stronger impact on ratification behaviour than domestic factors, such as democracy and income.

Our findings have important analytical and policy implications. They demonstrate that taking interdependencies in the international system seriously, not only in theoretical work but also in empirical models of international co-operation, increases the explanatory value of such models. Heeding Galton's advice not to examine the effects of unit-internal and unit-external variables in isolation also turns out to be useful in the study of international politics. Further research should find out whether our results hold up in other policy areas, or whether, for particular theoretical reasons, we should expect the effects of international linkages to vary across issue areas.

From a policy perspective, our findings suggest that ratification dynamics are important and offer room for proactive policies that promote global governance efforts. While it is obviously difficult to boost income, democracy and other domestic factors that promote co-operation in laggard countries in the short to medium term and at acceptable cost, our results demonstrate that countries interested in the effective formation of global governance systems can positively influence laggard country behaviour by moving ahead with ratification. Our results suggest that 'entangling' reticent countries in more international organizations can also be helpful in promoting the formation of specific global governance systems.

The following section develops the theoretical arguments and hypotheses to be tested. We then describe the data and methods used and present the results of the empirical analysis before concluding with a discussion of the implications of our findings.

(Fnote continued)

Liberalism', International Organization, 60 (2006), 781-810; Beth A. Simmons and Zachary Elkins, 'The Globalization of Liberalization: Policy Diffusion in the International Political Economy', American Political Science Review, 98 (2004), 171-89; Hugh Ward, 'International Linkages and Environmental Sustainability: The Effectiveness of the Regime Network', Journal of Peace Research, 43 (2006), 149-66.

23 David B. Carter and Curtis S. Signorino, 'Back to the Future: Modeling Time Dependence with Binary Data’ (Working Paper, University of Rochester, Department of Political Science, 2009). 


\section{LINKAGES BETWEEN STATES AND THE INTERNATIONAL SYSTEM}

We are primarily interested in the extent to which linkages between states and the international system and with each other influence international co-operation - in our case, the ratification of global environmental treaties - relative to domestic factors. Therefore, we first conceptualize international linkages in terms of the political and economic integration of countries into the international system as well as contingent behaviour, and then we present a set of hypotheses on the effects of these external factors. While our arguments on the effects of integration into the international system pertain to relatively amorphous influences that result from being part, in varying degrees, of the 'international community', contingent behaviour views ratification choices as being influenced by the behaviour of specific other states in the same issue area. In a second step, we then turn to internal factors and present arguments on how democracy and income are likely to influence countries' ratification behaviour.

Although the term globalization has been very prominent in political discourses since the early 1990s, its connotations vary widely across scientific disciplines, individual studies and policy contexts. For instance, while many economists define globalization somewhat narrowly as the international integration of markets in goods, services and capital, others stress cultural homogeneity and 'harmonization of economic institutions'. ${ }^{24}$ International political economy (IPE) scholars, in particular, devote much attention to institutionalized efforts to increase international co-operation among states in issue areas ranging from economic (for example, trade) to social (for example, illicit human trafficking) to security (such as terrorism) to environmental (such as climate change) issues. Indeed, states often commit to a particular course of action by joining international treaties on a variety of issues, thus signalling some convergence in economic, social and environmental thinking and practice. That is, the very fact that states are to an increasing extent seeking and implementing international or even global solutions to transboundary problems can serve as an indicator of globalization. Consequently, in this article we define linkages of states with the international system (and by implication with each other) in a broad sense as involving both political and economic integration into the international system.

\section{Involvement in International Organizations}

With regard to international political integration we assume that countries that are already 'entangled' in a larger network of international organizations - for example, the Bretton Woods institutions and specialized agencies of the United Nations (UN) - are more likely to adopt this co-operative behaviour also in other issue areas and with regard to other forms of international co-operation. Our argument postulates, therefore, that more extensive membership in international organizations (IOs) motivates states to behave more co-operatively also when it comes to forms of international co-operation that lie outside the scope of specific international organizations they have joined at some prior time.

It is important to recognize the differences between international organizations and global environmental treaties, the specific form of international co-operation we are interested in. To be recognized as an international organization, an organization has to be highly institutionalized, which is reflected, for example, in the fact that IOs possess a

24 Daniel Drezner, 'Globalizers of the World, Unite!', Washington Quarterly, 21 (1998), 207-25; Jeffrey Sachs, 'International Economics: Unlocking the Mysteries of Globalization', Foreign Policy, 110 (1998), 97-111. 
permanent secretariat and hold regular meetings. ${ }^{25}$ This implies that IOs constitute the most formal kind of international co-operation. In addition, IOs are set up to deal with a variety of issues that are usually not connected to environmental topics. In contrast, to be counted as an international treaty, the only requirement that needs to be fulfilled according to the 1969 Vienna Convention on the Law of Treaties is that the agreement is 'an international agreement concluded between States in written form and governed by international law' in which states express their 'consent to be bound'. ${ }^{26}$ Hence, multilateral environmental agreements are usually less institutionalized than international organizations and they are, by definition, limited in their scope to environmental topics.

However, both international organizations and multilateral treaties allow states to co-ordinate their behaviour and thereby achieve benefits from mutual co-operation. ${ }^{27}$ Consequently, we argue that membership in international organizations signals a general willingness of states to behave co-operatively in international matters, which states may also carry over to other very particular issue areas such as environmental policy.

Liberal institutionalism posits that, under conditions of interdependence, uncertainty and high transaction costs, states establish international organizations to facilitate cooperation. That is, IOs, by increasing information and decreasing transaction costs and uncertainty, facilitate international negotiations on new agreements or revision of existing ones, and they reduce the risk of opportunism in implementing international commitments. ${ }^{28}$ More generally, IOs are assumed to move states away from pursuing relative gains and towards positive-sum outcomes, help them overcome collective action problems, and promote shared interests. ${ }^{29}$ In addition, they specify legitimate ways for states to handle domestic and international issues, ${ }^{30}$ encourage effective interstate bargaining, ${ }^{31}$ and assist states in solving complex technical problems in more efficient ways. ${ }^{32}$ Membership in IOs thus signals a government's general willingness to co-operate internationally and adopt rules and regulations that benefit other countries as well.

Although rational states choose to participate in international environmental agreements only when they estimate that the benefits accruing to them by implementing a particular treaty will be larger than the benefits of unilateral efforts, failure to ratify a treaty could lead to reciprocal actions by other states that would undermine the collective effort. ${ }^{33}$

25 Jon C. Pevehouse, Timothy Nordstrom and Kevin Warnke, 'The COW-2 International Organizations Dataset Version 2.0', Conflict Management and Peace Science, 21 (2004), 101-19.

26 Anthony Aust, Modern Treaty Law and Practice (Cambridge: Cambridge University Press, 2000).

27 Robert Keohane, After Hegemony: Cooperation and Discord in the World Political Economy (Princeton, N.J.: Princeton University Press, 1984).

28 Keohane, After Hegemony; Haas et al., Institutions for the Earth; Mitchell, 'Regime Design Matters'; Kenneth W. Abbott and Duncan Snidal, 'Why States Act through Formal International Organizations', Journal of Conflict Resolution, 42 (1998), 3-32.

29 Oran Young, International Governance: Protecting the Environment in a Stateless Society (Ithaca, N.Y.: Cornell University Press, 1994); Young, The Effectiveness of International Environmental Regimes.

30 John W. Meyer, David J. Frank, Ann Hironaka, Evan Schofer and Nancy Brandon Tuma, 'The Structuring of a World Environmental Regime, 1870-1990', International Organization, 51 (1997), 623-51.

31 Charles Boehmer, Erik Gartzke and Timothy Nordstrom, 'Do International Organizations Promote Peace?' World Politics, 57 (2004), 1-38.

32 David Mitrany, A Working Peace System (Chicago: Quadrangle, 1966); Ernst Haas, Beyond the Nation-State (Palo Alto, Calif.: Stanford University Press, 1964).

33 Axelrod and Keohane, 'Achieving Cooperation under Anarchy', p. 250, state that 'International regimes do not substitute for reciprocity; rather they reinforce and institutionalize it, ... delegitimizing defection and thereby making it more costly'. 
Reciprocity becomes even more important if we take into account that countries interact in many issue areas at the same time and that these issues are linked. For example, when a country fails to ratify an environmental treaty, it may have to worry about other countries' refusal to ratify, say, a trade agreement. Moreover, being a member of several IOs but refusing to co-operate in the realm of international environmental co-operation may entail 'audience costs' in terms of credibility and reputation losses at home and abroad. ${ }^{34}$ As noted by Simmons, credibility has become essential to successful resolution of some of the most important issues states face today, such as environmental degradation. ${ }^{35} \mathrm{We}$ assume that such effects tend to grow in importance as a country joins more IOs, and also because many IOs deal with a wide variety of issues and can thus establish more linkages across issues.

The arguments outlined in the previous paragraph are likely to be of special importance in the field of environmental co-operation. Environmental protection and thus also ratification of multilateral environmental treaties means that countries have to forego certain benefits in other areas, such as economic growth. Consequently, low-income countries in particular may often not be willing to join such treaties. However, if these countries are already entangled in a larger network of international organizations, it may be possible to 'get them on board' through issue linkages, assistance, reciprocal action or reputational mechanisms. Recent research in fact shows that membership in international organizations and environmental international non-governmental organizations (EINGOs) plays an important role in environmental protection policies of less developed countries. ${ }^{36}$

In summary, the 'entanglement' argument relies both on liberal institutionalist and on what one might call 'sociological' assumptions. Greater involvement in international organizations fosters co-operative behaviour by reducing transactions costs and creating opportunities for diffuse reciprocity. It also has a 'socialization' effect in terms of creating norms of appropriateness. Hence, being a member of international organizations in general might lead governments to value the more generic benefits of international cooperation and thus to adopt this co-operative behaviour to very different issue areas and with regard to different forms of international co-operation.

HYPOTHESIS 1: Countries that are more involved in international organizations are more likely to join international environmental agreements.

\section{Integration in the World Economy}

The impact of trade on the environment has been the subject of an extensive and controversial debate in both political and academic circles. Moreover, it is amenable to relatively

34 Beth A. Simmons, 'Credibility, Costs, and Institutions: Cooperation on Economic Sanctions', World Politics, 45 (1993), 406-32; Jonathan Mercer, Reputation and International Politics (Ithaca, N.Y.: Cornell University Press, 1996).

${ }^{35}$ Simmons, 'Credibility, Costs, and Institutions'.

${ }^{36}$ Gabriele Ruoff, 'Grow Rich and Clean Up Later? Joint Effects of International Integration and Democracy on Environmental Quality in Developing Countries' (doctoral dissertation, CIS, ETH Zurich, 2009); Andrew K. Jorgenson, 'Foreign Direct Investment and the Environment, the Mitigating Influence of Institutional and Civil Society Factors, and Relationships between Industrial Pollution and Human Health: A Panel Study of Less-Developed countries', Organization and Environment, 22 (2009), 135-57; Andrew K. Jorgenson, 'Political-Economic Integration, Industrial Pollution and Human Health: A Panel Study of Less-Developed Countries, 1980-2000', International Sociology, 24 (2009), 115-43. 
coherent theoretical arguments and empirical testing. This is why, in examining the effects of countries' integration into the world economy, we focus on trade effects. ${ }^{37}$

Neumayer, relying mainly on arguments commonly associated with the 'liberal peace' and arguments pertaining to reputation, coercion and signalling, posits that trade openness promotes participation in multilateral environmental agreements (MEAs). ${ }^{38}$ However, his empirical findings provide only weak statistical support for this hypothesis and he partly retracts by stating 'countries' willingness to cooperate in MEAs depends on whether the MEA under consideration is likely to threaten or accommodate the interests of exporters'. ${ }^{39}$ Prakash and Potoski examine participation rates in ISO 14001, a widely used environmental certification system under which firms can voluntarily subscribe to certain standards of green behaviour. ${ }^{40}$ They find 'that trade linkages encourage ISO 14001 adoption if countries' major export markets have adopted this voluntary regulation'. ${ }^{41}$ In contrast, Beron et al. and Wagner, in studies on the Montreal Protocol, find that trade interdependence had no significant effect either on ratification or its timing. ${ }^{42}$

Studies such as these offer important insights into whether and how economic integration affects environmental policy in general and environmental treaty ratification in particular. But these insights remain vulnerable to three types of criticism. First, virtually all studies focus on one or very few environmental policy areas; thus, it remains open whether their findings can be generalized across a wider range of environmental policy issues.

Secondly, to explain co-operation, almost all existing studies rely on the 'liberal peace' argument, which postulates that trade between two states increases the economic costs of war for both participants and consequently reduces the probability of conflict. ${ }^{43}$ However, we think that the 'liberal argument' is not appropriate for the examination of ratification behaviour because decisions on whether to ratify an environmental treaty depend heavily on domestic considerations concerning the effects on one's own competitiveness. Our argument on the effect of trade on multilateral environmental treaty ratification thus follows standard trade theory.

Thirdly, the positive effect of trade observed for ISO 14001 is closely connected to the trading-up argument. ${ }^{44}$ This argument holds that greener jurisdictions can 'export'

37 We are aware that international economic integration is not limited to international trade, and that capital and labour mobility might be as important; but we leave their analysis to future research.

38 Neumayer, 'Does Trade Openness Promote Multilateral Environmental Cooperation?'

39 Neumayer, 'Does Trade Openness Promote Multilateral Environmental Cooperation?’ p. 831.

40 Aseem Prakash and Matthew Potoski, 'Racing to the Bottom? Trade, Environmental Governance, and Iso 14001', American Journal of Political Science, 50 (2006), 350-64.

41 Prakash and Potoski, 'Racing to the Bottom?' p. 350.

42 Kurt J. Beron, James C. Murdoch and Wim P.M. Vijverberg, 'Why Cooperate? Public Goods, Economic Power, and the Montreal Protocol', Review of Economics and Statistics, 85 (2003), 286-97; Ulrich J. Wagner, 'Estimating Strategic Complementarities in a Dynamic Game of Timing: The Case of the Montreal Protocol' (Working Paper, The Earth Institute, Columbia University, 2008).

43 John R. Oneal and Bruce Russett, 'Assessing the Liberal Peace with Alternative Specifications: Trade Still Reduces Conflict', Journal of Peace Research, 36 (1999), 423-42; Erik Gartzke, 'The Capitalist Peace', American Journal of Political Science, 51 (2008), 166-91; Katherine Barbieri, The Liberal Illusion: Does Trade Promote Peace? (Ann Arbor: University of Michigan Press, 2002), however, finds that more trade leads to more conflict. See Gerald Schneider, Katherine Barbieri and Nils Petter Gleditsch, eds, Globalization and Armed Conflict (Lanham, Md.: Rowman and Littlefield, 2003), for a survey of the literature.

44 David Vogel, 'Trading up and Governing Across: Transnational Governance and Environmental Protection', Journal of European Public Policy, 4 (1997), 556-71. 
their preferences and standards to other countries via trade relationships. However, the trading-up effect is likely to materialize only under quite narrowly defined conditions. In a country-to-country context, the principal trading-up mechanism - market access restrictions for polluting goods imposed by the importing country - operates primarily with respect to the environmental properties of products (for example, cars with or without catalytic converters; that is, product regulation), but to a much lesser extent with respect to production processes. ${ }^{45}$ Many international environmental issues, such as climate change mitigation or marine oil pollution, concern production processes rather than the properties of internationally traded products. We posit that a closer look at standard trade theory is necessary, and that this should make us rather sceptical about optimistic (trading-up) views on the effect of trade on international environmental co-operation.

According to the Hecksher-Ohlin model, trade leads to more production of goods that are intensive in the factor that is abundant in the country concerned. Consequently, comparative advantage derives from the distribution of world endowments of the factors of production (the factor endowment theory). If this assumption is correct, developed countries, which are more capital abundant, may become 'dirtier' with free trade because capital-intensive production tends to cause more pollution. Therefore, controlling for other influences (such as income or democracy), they will be more reluctant to participate in international environmental agreements that hamper their comparative advantage in the production of polluting goods (regulatory chill effect). If, however, the comparative advantage derives from policy related differences across countries in tolerance of pollution (the pollution haven or risk-shifting hypothesis), then the less developed countries, which tend to be more labour than capital abundant, are likely to be more reluctant to engage in international environmental co-operation. That is, we should then expect poorer countries to engage in more polluting production as a function of growing international trade due to the pollution haven effect; hence, they should also be more reluctant to ratify environmental agreements that hurt their comparative advantage which derives from laxer environmental regulation.

Depending on whether the factor endowment or pollution haven effect dominates, richer or poorer countries will, for reasons of competitiveness, be more reluctant to join international environmental agreements. Consequently, we expect negative trade effects on average because both the factor endowments and the pollution haven effect push in this direction. In other words, the more intensively a country trades, the greater the loss from a reduction in trade. Environmental regulation increases the costs of producing exportables and thus reduces exports (that is, it acts like a tax on exports). Consequently, the trade-off between gains from a cleaner environment and losses from lower exports is more adverse for more open economies.

HYPOTHESIS 2: Countries that trade intensively are less likely to join international environmental agreements.

\section{Contingent Behaviour}

Decisions by countries on whether to ratify international agreements are most probably influenced by what other countries do in the respective policy area. In other words,

\footnotetext{
45 Thomas Bernauer and Ladina Caduff, 'In Whose Interest? Pressure Group Politics, Economic Competition and Environmental Regulation', Journal of Public Policy, 24 (2004), 99-126.
} 
nations pay attention to or even mimic their peers. ${ }^{46}$ In view of the large game theoretic and institutionalist literature on international co-operation, this claim may sound almost trivial. Surprisingly, however, large- $N$ empirical research on international co-operation has - perhaps because it is so obvious - not paid much attention to contingent behaviour.

An exception is the recent research, primarily under the label of 'policy diffusion', that has started to explore the role of contingent behaviour more systematically. ${ }^{47}$ Simmons et al. define diffusion as follows: 'International policy diffusion occurs when government policy decisions in a given country are systematically conditioned by prior policy choices made in other countries (sometimes mediated by the behaviour of international organizations or even private actors or organizations)'. ${ }^{48}$ Most studies take several diffusion mechanisms into account. For example, Elkins et al. find that coercion and competition play a role in the spread of bilateral trade agreements. ${ }^{49}$ Simmons and Elkins report that both competition and learning matter for economic liberalization. ${ }^{50}$ Henisz et al. observe that coercion, common norms and competition contribute to the spread of marketoriented reforms. ${ }^{51}$ Simmons finds evidence that countries are more likely to make and honour a legal agreement such as the IMF's Article VIII ${ }^{52}$ if their neighbour countries are doing so. 53

Even though all of the above-mentioned mechanisms may play a role in motivating states to ratify international environmental treaties, we suspect that most of them are quite highly correlated and also shaped by other factors that we regard as determinants of ratification behaviour (such as trade openness, democracy, income). We believe that it is reasonable to assume that all of the aforementioned mechanisms are at work more prominently in cases where countries share some common characteristics, such as the same level of economic development and location in the same geographic region. In other words, we argue that any given country's ratification behaviour is influenced by ratification behaviour in its 'peer group'.

Our study thus contributes to the increasing literature that addresses what is known as Galton's problem. As outlined above, Galton's problem points to the difficulty of assessing whether a government makes a specific policy choice because a specific cause or

${ }^{46}$ Simmons et al., 'Introduction: The International Diffusion of Liberalism'.

47 Zachary Elkins, Andrew Guzman and Beth Simmons, 'Competing for Capital: The Diffusion of Bilateral Investment Treaties, 1960-2000', International Organization, 60 (2006), 811-46; Simmons et al., 'Introduction: The International Diffusion of Liberalism'; Covadonga Meseguer, 'Policy Learning, Policy Diffusion and the Making of a New Order', Annals of the American Academy of Political and Social Sciences, 598 (2005), 67-82; Covadonga Meseguer, 'Learning and Economic Policy Choices', European Journal of Political Economy, 22 (2006), 156-78; David Levi-Faur, 'The Global Diffusion of Regulatory Capitalism', Annals of the American Academy of Political and Social Sciences, 598 (2005), 12-33; Zachary Elkins and Beth Simmons, 'On Waves, Clusters, and Diffusion: A Conceptual Framework', Annals of the American Academy of Political and Social Sciences, 598 (2005), 33-51; Witold J. Henisz, Bennet A. Zelner and Mauro F. Guillén, 'International Coercion, Emulation and Policy Diffusion: Market-Oriented Infrastructure Reforms, 1977-1999', American Sociological Review, 70 (2005), 871-97; Simmons and Elkins, 'The Globalization of Liberalization'.

${ }^{48}$ Simmons, Dobbin and Garrett, 'Introduction: The International Diffusion of Liberalism', p. 787.

${ }^{49}$ Elkins et al., 'Competing for Capital'.

${ }^{50}$ Simmons and Elkins, 'The Globalization of Liberalization'.

${ }^{51}$ Henisz et al., 'International Coercion, Emulation and Policy Diffusion'.

52 Article VIII prohibits restrictions on a country's current account (Beth A. Simmons, 'International Law and State Behavior: Commitment and Compliance in International Monetary Affairs', American Political Science Review, 94 (2000), 819-36, p. 820).

${ }^{53}$ Simmons, 'International Law and State Behavior'. 
event impacts on all countries or on a given pair or group of countries; for example, pressures arising from globalization may force it to do so, because of internal characteristics, or because this government follows the specific policy choice of another government with whom it shares some common characteristics. By differentiating between contingent behaviour, the effects of international political and economic integration, and the effects of domestic forces driving treaty ratification, the approach taken in this article takes into account Galton's problem.

Our hypotheses identify peer group effects in three forms:

HYPOTHESIS 3a: The propensity of a country to join an international environmental agreement increases with the number of other countries that have joined this agreement.

HYPOTHESIS $3 b$ : The propensity of a country to join an international environmental agreement increases with the share of other countries in the same geographic region that have joined this agreement.

HYPOTHESIS 3c: The propensity of a country to join an international environmental agreement increases with the share of other countries in the same income bracket that have joined this agreement.

While the last three sections have discussed the effects of unit-external or international driving forces, we now turn to internal or domestic determinants of countries' ratification behaviour.

\section{DOMESTIC FACTORS}

Most of the recent literature on international co-operation, and international environmental politics in particular, views both income and democracy as factors that promote co-operation. Hence, we conceptualize these two variables as the two domestic (internal) factors with reference to which we assess the effects of international linkages and relegate other variables to the status of control variables.

\section{Income}

The existing environmental politics and economics literature concentrates on the effect of income on environmental quality (pollution) rather than treaty ratification behaviour. Translation of its arguments on the income-pollution relationship to ratification behaviour is straightforward, however, because we can assume that countries that are more willing to improve their environmental quality are also more willing to join international treaties in this realm.

The large body of theoretical and empirical literature that focuses on economic determinants of environmental quality has led to the identification of an important empirical pattern, the so-called environmental Kuznets curve. ${ }^{54}$ Many (but not all) forms of environmental degradation first become worse and then improve as income per capita increases. The turning points of the curve vary considerably across pollutants and countries. The standard interpretation of this pattern is that environmental quality is a

\footnotetext{
54 Thomas M. Selden and Daqing Song, 'Environmental Quality and Development: Is there a Kuznets Curve for Air Pollution Emissions?' Journal of Environmental Economics and Management, 27 (1994), 147-62; Gene M. Grossman and Alan B. Krueger, 'Economic Growth and the Environment', Quarterly Journal of Economics, 110 (1995), 353-77.
} 
luxury good in the initial stages of socio-economic development. Poor countries facing a trade-off between protecting the environment and improving material living standards opt for the latter. Once significant gains have been made in living standards, the opportunity cost of stricter environmental policies becomes (relatively) smaller and constituencies are prepared to accept lower economic or personal income growth (the two may not be identical) to obtain less pollution. That is, environmental quality becomes a 'normal' good. Assuming that this pattern applies not only to local but also to transboundary environmental goods, and that international treaties are a necessary (though not sufficient) condition for achieving improvements in environmental quality, we expect that a country's willingness to ratify an international environmental treaty is positively correlated with income. The empirical analysis will examine both linear and non-linear income effects.

\section{Democracy}

Many authors have argued that democratic countries are more likely to make credible international policy commitments than their non-democratic counterparts. ${ }^{55}$ The reasons are that democratic institutions are stronger compared to non-democracies, democratic decision-makers are more accountable to their electorates, audience costs in democracies are higher, and so is the transparency. This implies that democratic dyads are more likely to be able to solve transboundary problems through mutual international commitments. ${ }^{56}$ We cannot directly deduce from this argument, however, that (in a monadic sense) democratic countries are more likely to join international agreements. We submit, nonetheless, that democracy is likely to have a positive effect on participation in international environmental agreements, but the reasons are somewhat different from the aforementioned ones. Arguments relating democracy and international environmental commitment can be grouped into demand and supply side arguments. ${ }^{57}$

As to the demand side, democratic political systems offer a much higher degree of civil liberties, such as freedom of speech, freedom of the press and freedom of association. ${ }^{58}$ Such liberties imply that citizens are better informed by independent mass media and other sources (such as NGOs) about environmental problems and government policies. They also have more opportunities to express their opinions freely and organize around alternative political views, and thus they can impose higher audience costs on policy-makers

55 James D. Fearon, 'Domestic Political Audience and the Escalation of International Disputes', American Political Science Review, 88 (1994), 577-92; Kurt Taylor Gaubatz, 'Democratic States and Commitment in International Relations', International Organization, 50 (1996), 109-39; Brett Ashley Leeds, 'Domestic Political Institutions, Credible Commitments, and International Cooperation', American Journal of Political Science, 43 (1999), 979-1002; Lisa Martin, Democratic Commitments: Legislatures an International Cooperation (Princeton, N.J.: Princeton University Press, 2000); Edward D. Mansfield, Helen V. Milner and Peter B. Rosendorff, 'Why Democracies Cooperate More: Electoral Control and International Trade Agreements', International Organization, 56 (2002), 477-513.

${ }^{56}$ Anna Kalbhenn, 'A River Runs Through It: Democracy, International Interlinkages and Cooperation over Shared Resources' (NCCR Working Paper No. 32, 2009), for example, shows that democratic pairs of countries tend to co-operate more in international river management issues than non-democratic or mixed dyads. See also Thomas Bernauer and Patick Kuhn, 'Is There an Environmental Version of the Kantian Peace? Insights From Water Pollution in Europe', European Journal of International Relations, 16 (2010), $77-102$.

${ }^{57}$ Michèle B. Baettig and Thomas Bernauer, 'National Institutions and Global Public Goods: Are Democracies More Cooperative in Climate Change Policy?' International Organization, 63 (2009), 281-308.

58 Rodger A. Payne, 'Freedom and the Environment', Journal of Democracy, 6 (1995), 41-55. 
who renege on promises. ${ }^{59}$ Consequently, at any given level of (objective) environmental risk exposure and/or income, public demand by the median voter and/or politically influential interest groups for risk mitigation is likely to be stronger in democracies than in non-democracies. That is, our expectation is that the higher the level of civil liberties, the higher the probability that a country ratifies an environmental treaty.

As to the supply side, many authors have argued that non-democratic political systems are likely to under-provide public goods, including environmental quality. ${ }^{60}$ They are typically governed by small elites that use the resources of their country to generate personal wealth and funnel income from the population into their own pockets. If the costs of stricter environmental policies mandated by an international environmental treaty fall disproportionately on the governing elites in the sense of opportunity costs from spending tax revenue on environmental protection instead of accumulating rents while the benefits are uniformly dispersed throughout the population (for example, cleaner air), then these elites would have little incentive to ratify this treaty. Conversely, the median voter in a democracy incurs lower marginal cost from environmental policies relative to the economic and political elite in non-democracies. ${ }^{61}$

Congleton argues, however, that policy makers may have a short time horizon, leading to less stringent environmental regulation. ${ }^{62}$ Many forms of environmental degradation in fact develop slowly and over long periods of time (for example, climate change, loss of biodiversity, air and water pollution). Hence, their mitigation requires a long time horizon. Assuming that authoritarian rulers tend to have a shorter time horizon, we can conclude that democracies enact stricter environmental regulation than non-democracies. But quite the reverse, one might also argue that elected governments have shorter planning horizons than non-elected governments because of political myopia (maximizing votes at the next election). ${ }^{63}$ Since the social costs of current economic behaviour and political choices often materialize only over the long term and burden future generations and future politicians, democratic leaders may refrain from ratifying international environmental treaties that impose high short-term costs. Their autocratic counterparts, in contrast, do not face democratic elections and can take more costly decisions (stricter environmental policies) with longer term benefits without fear of been punished by myopic voters. Consequently, democracies might be less willing to ratify international environmental treaties.

59 Branislav L. Slantchev, 'Politicians, the Media, and Domestic Audience Costs', International Studies Quarterly, 50 (2006), 445-77.

${ }^{60}$ For example, Congleton, 'Political Institutions and Pollution Control'; Mancur Olson, 'Dictatorship, Democracy and Development', American Political Science Review, 87 (1993), 567-76; Martin McGuire and Mancur Olson, 'The Economics of Autocracy and Majority Rule: The Invisible Hand and the Use of Force', Journal of Economic Literature, 34 (1996), 72-96; William Niskanen, 'Autocratic, Democratic and Optimal Government', Economic Inquiry, 35 (1997), 464-79; David Lake and Matthew Baum, 'The Invisible Hand of Democracy: Political Control and the Provision of Public Service', Comparative Political Studies, 34 (2001), 587-621; Bruce Bueno de Mesquita, Alastair Smith, Randolph M. Siverson and James D. Morrow, The Logic of Political Survival (Cambridge, Mass.: MIT Press, 2003); Thomas Bernauer and Vally Koubi, 'Effects of Political Institutions on Air Quality', Ecological Economics, 68 (2009), 1355-65.

61 Bernauer and Koubi, 'Effects of Political Institutions on Air Quality'.

62 Congleton, 'Political Institutions and Pollution Control'.

63 Bueno de Mesquita et al., The Logic of Political Survival, empirically show that once autocratic leaders have succeeded in surviving in office during the initial years of seizing power, then they survive in office longer than their democratic counterparts (chap. 7). 
Overall, public demand for environmental risk mitigation is likely to be stronger in democracies than in non-democracies (demand side). Whether democratic political elites are more inclined to satisfy such demand than non-democratic elites remains an empirical question. The existing literature has, thus far, found mainly positive effects. ${ }^{64}$ Even though these studies concentrate on only one or very few international environmental agreements, we follow those findings and expect (albeit with caution) that more democratic countries are more likely to ratify international environmental agreements.

\section{CONTROL VARIABLES}

\section{Power}

We expect that power, defined in terms of a country's economic size and/or population, has a relevant although theoretically ambiguous effect on ratification behaviour. Neumayer, for instance, argues that powerful states are more likely to participate in multilateral environmental agreements 'in order to demonstrate their importance in world politics, of which the environment represents one part. In other words, important countries want to be seen as good citizens and leaders in world environmental affairs'. ${ }^{65}$ This is only one possibility, and even in this case we suspect that participation is likely to be motivated primarily by countries' concerns for their own safety and well-being, rather than the desire to be seen as good world citizens by someone else. The other, not so glamorous possibility, is that more powerful states may choose not to ratify because they are likely to get away with such behaviour at lower cost. ${ }^{66}$ In other words, the effect of power is theoretically ambiguous, but potentially important. We control for this effect without a prior assumption concerning its direction.

\section{Domestic environmental quality}

Countries' willingness to participate in international environmental agreements may reflect the degree to which environmental degradation impinges upon their national welfare. Sprinz and Vaahtoranta argue that 'the worse the state of the environment, the greater the incentives to reduce the ecological vulnerability of the state'. ${ }^{67}$ If we subscribe to this argument, we should expect that countries with bigger domestic pollution problems are more likely to join international environmental agreements because there is greater public demand for more stringent environmental policies, and/or because the government seeks to tie its hands through international commitments in order to be able to impose stricter policies on opposing domestic interests. In addition, we may also expect that states whose environmental quality is improving or has improved as the result of strict domestic environmental regulation are likely to face lower domestic political and economic hurdles in ratifying international environmental commitments. However, given

64 See, for example, Neumayer, 'Do Democracies Exhibit Stronger International Environmental Commitment?'; Zilbauer, 'Determinants of International Environmental Cooperation'; Von Stein, 'The International Law and Politics of Climate Change'; Bernauer and Koubi, 'Effects of Political Institutions on Air Quality'; Baettig and Bernauer, 'National Institutions and Global Public Goods: Are Democracies More Cooperative in Climate Change Policy?'

65 Neumayer, 'Do Democracies Exhibit Stronger International Environmental Commitment?' p. 150.

66 The failure of the United States to ratify the Kyoto Protocol is a good example.

67 Detlef Sprinz and Tapani Vaahtoranta, 'The Interest-Based Explanation of International Environmental Policy', International Organization, 48 (1994), 77-105, p. 79. 
that more polluted countries also face higher abatement costs, it is reasonable to assume that these costs might deter governments from ratifying a cost imposing treaty. Consequently, we expect domestic environmental quality to have an ambiguous effect on ratification behaviour.

\section{Geographic Region}

While Hypothesis $3 b$ (see above) focuses on the effect of regional ratification behaviour in terms of contingent behaviour, we also include regional dummy variables to capture any effects that the geographical location of a country might have on its propensity to ratify an agreement. For the empirical analysis, we select from the very large number of international environmental agreements only those that are, in principle, open to all countries globally. However, some agreements may, because of the very nature of the issue they deal with, attract more countries from some regions than from others. For example, African countries might be less eager to join agreements to protect arctic seals and polar bears (even though these agreements are open to them), whereas many Western European countries may be less interested in efforts to cope with desertification.

\section{EMPIRICAL ANALYSIS}

We test the above hypotheses with a new panel dataset covering 180 countries' ratification behaviour (ratification: yes/no) towards international environmental treaties from 1950 to $2000 .^{68}$ The unit of analysis is the treaty-country pair per year. Each treaty enters the dataset at the moment when it becomes open for ratification and is then paired with all countries that existed at this particular point in time. Hence, in contrast to the more common country-dyad approach, we do not pair countries with other countries but countries with treaties. Each treaty-country pair stays in the dataset until the year when the respective country ratifies the treaty. For each year we estimate the probability of a particular country ratifying a treaty, as described in a later section on statistical method. This approach allows us to include both country- and treaty-specific characteristics. In this article, the term 'treaty-specific characteristics' relates to any condition that varies across treaties, but not across countries. We proceed by first defining the variables used in the analysis and then discussing the statistical method. The empirical part concludes with the presentation and discussion of the results.

\section{Dependent and Independent Variables}

The following paragraphs briefly describe the data used. Tables 1 and 2 provide descriptive statistics for all variables and the web appendix contains more detailed descriptive statistics for the dependent (ratification) variable.

The dependent variable is defined in terms of the ratification of a multilateral environmental treaty. We coded ratification in binary form. For each year in which a treaty is not ratified by a particular country, the respective treaty-country pair is coded as zero (0). The dependent variable takes the value one (1) in the year the country ratifies the treaty, whereupon this particular treaty-country pair leaves the dataset. The latter approach is

\footnotetext{
${ }^{68}$ In this article, we use the term 'ratification' to indicate any form of binding commitment (as opposed to signature). Depending on the specific legal context, this commitment can also be expressed by adhesion, accession, etc.
} 


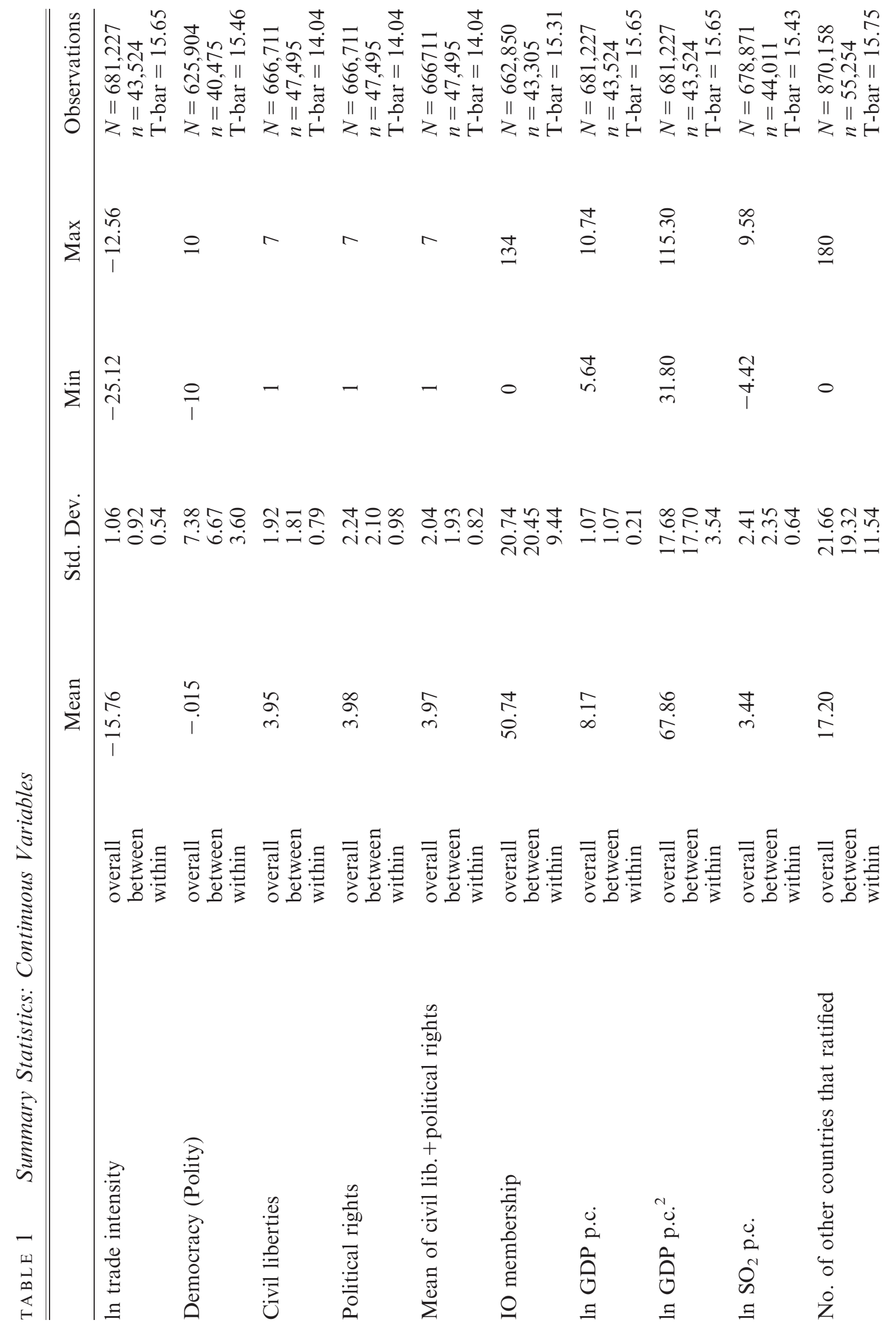




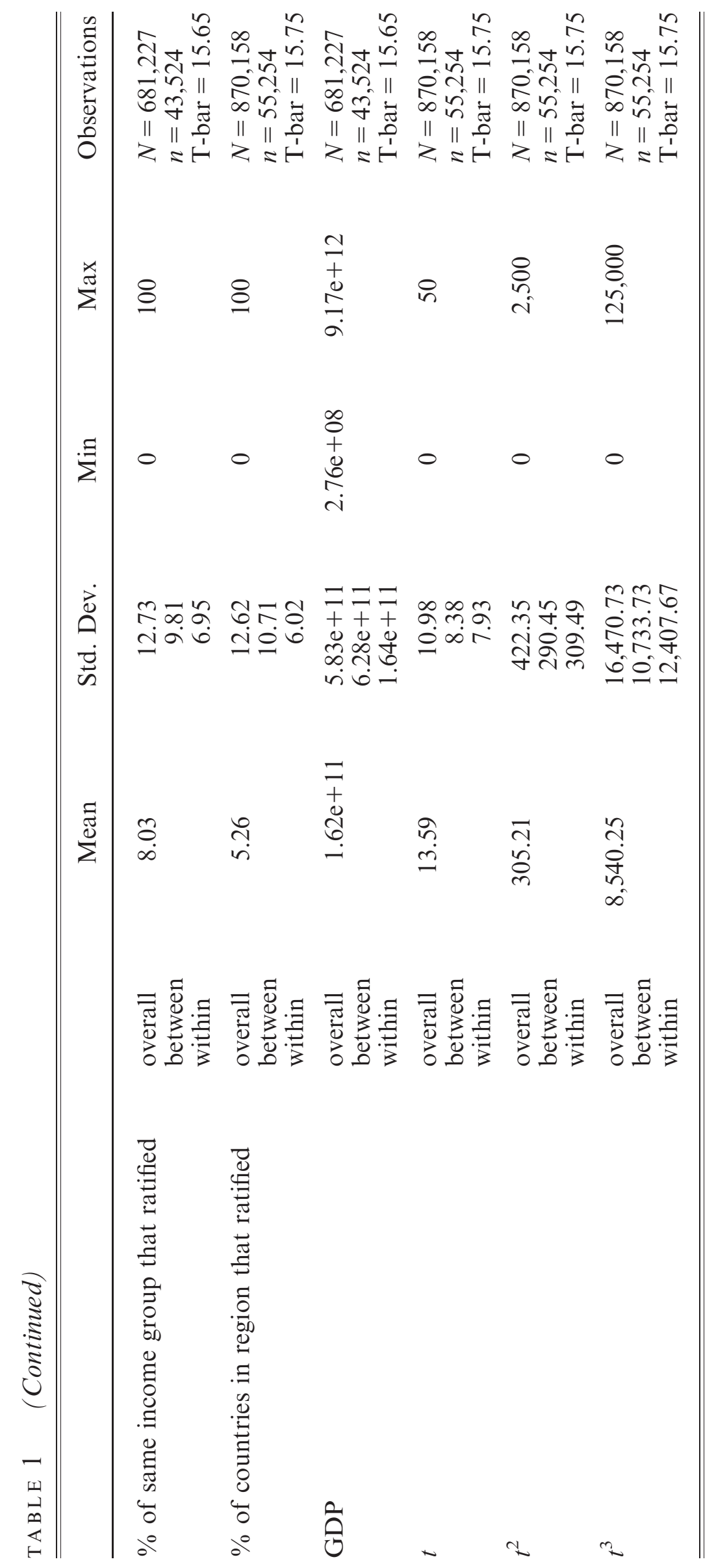


TABLE 2 Frequencies of Dummy Variables with Percentages in Parenthesis

\begin{tabular}{lcr}
\hline \hline & 0 & \multicolumn{1}{c}{1} \\
\hline Ratification & $862,474(99.12)$ & $7,684(0.88)$ \\
Africa & $638,936(73.43)$ & $231,222(26.57)$ \\
North America & $862,538(99.12)$ & $7,620(0.88)$ \\
Latin America & $729,696(83.86)$ & $140,462(16.14)$ \\
East Asia & $773,973(88.95)$ & $96,185(11.05)$ \\
West Asia & $765,333(87.95)$ & $104,825(12.05)$ \\
United Kingdom & $470,067(54.02)$ & $400,091(45.98)$ \\
United States & $638,805(73.41)$ & $231,353(26.59)$ \\
Germany & $493,968(56.77)$ & $376,190(43.23)$ \\
Spain & $503,248(57.83)$ & $366,910(42.17)$ \\
France & $469,718(53.98)$ & $400,440(46.02)$ \\
Rusia & $629,378(72.33)$ & $240,780(27.67)$ \\
Brazil & $756,270(86.91)$ & $113,888(13.09)$ \\
China & $785,452(90.27)$ & $84,706(9.73)$ \\
India & $753,521(86.60)$ & $116,637(13.40)$ \\
\hline
\end{tabular}

necessary because leaving the treaty-country pair with code 1 in the dataset after ratification would indicate that the respective country ratified the treaty again and again in each subsequent year until 2000 (where our dataset ends). The data on treaties and ratifications were retrieved from the datasets by CIESIN and Mitchell. ${ }^{69} \mathrm{We}$ then eliminated from this data treaties that, in our assessment, are not environmental treaties or deal with environmental issues only at the margin, and treaties that are not open to all countries globally; and we re-coded the remaining data to fit the particular format used for this analysis. Our dataset includes 255 treaties. ${ }^{70}$ Whether particular treaties are not only in principle but also de facto open to all countries globally is not entirely clear in some cases. We have thus assessed the robustness of our statistical findings with alternative sample compositions (presented in the web appendix).

Involvement in international organizations: IO membership. Membership in international organizations (IO) is measured by the number of IOs of which a country is a member in any given year. The data are taken from the Correlates of War project. ${ }^{71}$ This project's IO dataset offers three distinct variables differentiated according to whether a state has full, associated or observer membership. In our principal models we use the most inclusive (or least 'stringent') variable, the one that includes full, associated and observer membership. We check the robustness of the results by using both the most narrowly defined variable, which includes only full membership, and the variable that includes full membership and observer status. Altogether, the Correlates of War project identifies 495 international organizations. The mean number of memberships per country is around fifty with Britain having the maximum number of memberships, 134.

${ }^{69}$ CIESIN, 'Environmental Treaties and Resource Indicators (ENTRI)' (2006), available at: http:// sedac.ciesin.columbia.edu/entri/, accessed 13 December 2006; Ronald B. Mitchell, 'International Environmental Agreements Database Project' (2002-08), Version 2007.1, available at: http://iea.uoregon.edu/, accessed 18 March 2008.

70 The number of treaties that has been ratified by a country varies between 132 in the case of France or 126 in the case of Great Britain and nine in the case of Somalia or only eight in the case of Bhutan.

${ }^{71}$ Pevehouse et al., 'The COW-2 International Organizations Dataset Version 2.0'. 
Integration in the world economy: trade intensity. We measure a country's trade intensity by the ratio of the sum of exports and imports to gross domestic product (GDP). ${ }^{72}$

Contingent behaviour. To test contingent behaviour effects we have created several variables. For Hypothesis 3a, we use a variable measuring the total number of states in the international system that have already ratified the particular treaty. Similarly, we include two variables measuring the percentage of countries from the same geographical group (region) and the percentage of countries from the same income group that have already ratified the particular treaty (Hypotheses $3 \mathrm{~b}$ and $3 \mathrm{c}$ ). Geographic regions are defined according to the IIASA world population programme definition. ${ }^{73}$ Following World Bank standards, we categorize countries into three income groups: low-income countries with a GDP per capita below $\$ 3,273$ USD, middle-income countries with a GDP between US\$3,273 and 11,115 per capita, and high-income countries with a GDP per capita above the latter amount. We use a one-year lagged value of all contingency variables.

Income: $\log$ value of GDP per capita. A country's wealth is measured by the log value of GDP per capita. ${ }^{74}$ As discussed in the theory section, income may also have a non-linear effect on the likelihood of ratifying international environmental treaties. We thus include also the squared value of the log of GDP per capita.

Democracy (demand side): civil liberties. We use the civil liberties component of the Freedom House Index to test whether more civil liberties increase the likelihood of ratifying global environmental treaties. The Freedom House organization rates all countries of the world on dimensions of political and civil rights. The civil liberties part of the index measures constraints, among other things, on: association and organizational rights (freedom of assembly, demonstration, political or quasi-political organizations including ad hoc issue groups, and free trade unions and farmers organizations); the rule of law and human rights (existence of an independent judiciary, and freedom from extreme government interference and corruption); and personal autonomy and economic rights (secured property rights, personal social freedoms, and equality of opportunity including freedom from exploitation by or dependency on employers, union leaders or bureaucrats). Freedom House rates countries on a 1 to 7 scale. In countries with a rating of 1, the law is unshaken and there is freedom of expression, assembly and association. Increasing numbers indicate that laws and traditions impinge increasingly on such freedoms until, in states ranked as 7 , citizens have no rights vis-à-vis the state and 'an overwhelming and justified fear of repression characterizes these societies' ${ }^{75}$ To facilitate

\footnotetext{
72 The data are taken from Kristian Skrede Gleditsch, 'Expanded Trade and GDP Data', Journal of Conflict Resolution, 46 (2002), 712-24; and Alan Heston, Robert Summers and Bettina Aten, 'Penn World Table Version 6.2' (Center for International Comparisons of Production, Income and Prices at the University of Pennsylvania, 2006).

${ }^{73}$ See http://www.iiasa.ac.at/Research/POP/proj01/countries.html. The regions are: Centrally Planned Asia, Central Asia, North Africa, Middle East, Sub-Saharan Africa, Latin America, Western Europe, Eastern Europe, North America, Pacific OECD, South Asia, Former Soviet Union, Pacific Asia.

${ }^{74}$ These data are taken from Gleditsch, 'Expanded Trade and GDP Data'.

${ }^{75}$ Freedom House, 'Methodology', see the website, http://www.freedomhouse.org/template.cfm? page $=351 \&$ ana_page $=341$ \&year $=2008$, accessed 2 November 2009 .
} 
intuitive interpretation, we transform the variable so that a higher value means a higher level of civil liberties ( 7 now represents the highest level of civil liberties).

Democracy (supply side). Supply side features of democracy are measured with an index capturing the extent of democratic participation in government. We use a composite index from the Polity IV dataset that includes the following elements: presence of competitive political participation, guarantees of openness and competitiveness of executive recruitment, and existence of institutionalized constraints on the exercise of executive power. Polity ranges from -10 (most autocratic) to +10 (most democratic). ${ }^{76} \mathrm{We}$ check the robustness of our results by using Vanhanen's democracy index as well as Freedom House's Political Rights Index. ${ }^{77}$

\section{Control Variables}

Power: $\log$ of population, $\log$ of GDP. To control for the effect of power, we use two variables: the log value of the population of a country, for which we use data from the Correlates of War dataset of national military capabilities; ${ }^{.7}$ and the log value of GDP, that is the economic size of a country. ${ }^{79}$ Since these variables are highly correlated, we include only one of them in any model and use the other for a robustness check.

Domestic environmental quality: $\log$ of $\mathrm{SO}_{2}$ emissions per capita. Since no composite index of domestic environmental quality exists for many countries and years, we rely on the log of sulphur dioxide $\left(\mathrm{SO}_{2}\right)$ emissions per capita as a proxy. ${ }^{80} \mathrm{We}$ use this admittedly crude proxy because $\mathrm{SO}_{2}$ emissions are, arguably, the most common form of air pollution and a very common target of environmental policy in most countries.

Region. We include dummy variables for world regions to control for specific features of environmental treaties that may attract countries from one region more than others. The regions are Eastern Asia, Western Asia, Africa, Latin America, Europe and North America. ${ }^{81}$

\section{STATISTICAL METHOD}

The unit of analysis is the country-treaty pair per year. That is, for each year in which a given treaty is open for ratification, it is paired with all potential member countries, so

${ }^{76}$ Keith Jaggers and Ted R. Gurr, 'Tracking Democracy's Third Wave with the Polity III Data', Journal of Peace Research, 32 (1995), 469-82; Monty G. Marshall and Keith Jaggers, 'Polity IV Project: Political Regime Characteristics and Transitions, 1800-2002', Dataset Users's Manual (Polity IV, 2002).

${ }_{77}$ Tatu Vanhanen, 'A New Dataset for Measuring Democracy, 1810-1998', Journal of Peace Research, 37 (2000), 251-65. The political rights element of the Freedom House Index, which is very close to the Polity IV measure of democracy, captures mainly the fairness and freedom of elections, that is, whether a government came to power by election or by non-democratic means; whether elections, if any, are free and fair; and whether an opposition exists and has the opportunity to take power with the consent of the electorate.

78 David J. Singer, Stuart Bremer and John Stuckey, 'Capability Distribution, Uncertainty, and Major Power War, 1820-1965', in Bruce Russet, ed., Peace, War, and Numbers (Beverly Hills, Calif.: Sage, 1972), pp. 19-48.

79 Gleditsch, 'Expanded Trade and GDP Data'.

${ }^{80}$ David I. Stern, 'Global Sulfur Emissions From 1850 to 2000', Chemosphere, 58 (2005), 163-75.

81 We have used a more differentiated definition of regions to assess contingency effects (see above). The regional dummies are defined in broader terms because their main goal is to control for any remaining effects on treaty ratification that may emanate from a less clearly defined set of geographic or ecological factors. 
that each observation is formed by a particular treaty, the country that may or may not have ratified the treaty, and the year this action did or did not take place. ${ }^{82} \mathrm{~A}$ treatycountry pair leaves the dataset in the year after the country has ratified the treaty, i.e. after the dependent variable has changed from zero to one. By combining all multilateral environmental treaties in one dataset, we introduce some heterogeneity between the treaties in our analysis. We deal with this issue of unit heterogeneity in several ways that are described in the section on robustness checks below.

Since we are dealing with a binary outcome variable (ratification: yes/no), we rely on the approach proposed by Carter and Signorino, ${ }^{83}$ which is similar to the binary-time-series-crosssectional (BTSCS) approach described in Beck et al. ${ }^{84}$ This approach views BTSCS data as grouped duration data in which the interval of observing the data is fixed to one year. Hence, this approach is analogous to a survival analysis, the difference being that the dependent variable in the BTSCS framework is observed yearly, whereas many survival models are designed for continuous time. We cross-checked our results using a complementary log-log model, which is equivalent to a proportional hazard model for interval censored (i.e. grouped duration) data. The results do not differ substantively and are presented in the web appendix. To model temporal dependence, time as well as its squared and cubic term $\left(t, t^{2}\right.$ and $\left.t^{3}\right)$ are included in the models. This approach acknowledges that a country's ratification behaviour today depends strongly on its ratification behaviour in the years before and thus controls for time effects. ${ }^{85}$ The use of $t, t^{2}$ and $t^{3}$ (cubic time polynomial) instead of cubic splines (which is recommended by Beck et $\mathrm{al}^{86}$ ) has the advantage of a more straightforward interpretation of the baseline hazard, whereas the approximation of the baseline hazard is at least as good as that with cubic splines. ${ }^{87}$ To assess the robustness of our results, we also use alternative statistical techniques (the results are presented in the web appendix).

The time frame of our analysis ranges from 1950 to 2000 . Although we have treaty ratification data for the time period before 1950 and after 2000, this is not the case for most independent variables. In some models that include variables, such as the civil liberties index of Freedom House, the time period is further reduced.

\section{RESULTS}

Table 3 reports the results from the regression of treaty ratification on the explanatory variables described above.

The first column in Table 3 shows the results of our principal explanatory model. ${ }^{88}$ The evidence supports Hypotheses 1 and 2: IO membership has a statistically significant

\footnotetext{
${ }^{82}$ Only in very rare circumstances does a country withdraw from a treaty it has already ratified. If this was the case, the particular country-treaty combination was reintegrated into the dataset.

${ }^{83}$ Carter and Signorino, 'Back to the Future'.

${ }^{84}$ Nathaniel Beck, Jonathan N. Katz and Richard Tucker, 'Taking Time Seriously: Time-Series-CrossSection Analysis with a Binary Dependent Variable', American Journal of Political Science, 42 (1998), 1260-88.

${ }^{85}$ In addition to the inclusion of $t, t^{2}$ and $t^{3}$, we test the robustness of our results by including time dummies and decade dummies. The decade dummies are a possibility to control for changing environmental consciousness over time and thus constitute an additional approach to dealing with time dependence in our model. The corresponding results can be found in the web appendix.

${ }_{87}^{86}$ Beck et al., 'Taking Time Seriously'.

${ }^{87}$ Carter and Signorino, 'Back to the Future'.

${ }^{88}$ All models were estimated using robust standard errors clustered by countries to control for the fact that observations for the same country may be more similar than observations across different countries.
} 
tA BLe $3 \quad$ Principal Models

\begin{tabular}{|c|c|c|c|c|c|}
\hline & (1) & (2) & (3) & (4) & $(5)$ \\
\hline IO membership & $\begin{array}{l}0.01 * * * \\
(0.00)\end{array}$ & $\begin{array}{l}0.01 * * * \\
(0.00)\end{array}$ & $\begin{array}{c}0.01 * \\
(0.00)\end{array}$ & $\begin{array}{l}0.01 * \\
(0.00)\end{array}$ & $\begin{array}{l}0.01 * * * \\
(0.00)\end{array}$ \\
\hline ln trade intensity & $\begin{array}{c}-0.12^{* *} \\
(0.05)\end{array}$ & $\begin{array}{c}-0.12^{* *} \\
(0.05)\end{array}$ & $\begin{array}{c}-0.09 \\
(0.06)\end{array}$ & $\begin{array}{c}-0.10 \\
(0.06)\end{array}$ & $\begin{array}{c}-0.13^{* *} \\
(0.06)\end{array}$ \\
\hline Number of other countries that ratified & $\begin{array}{l}0.02^{* * * *} \\
(0.00)\end{array}$ & $\begin{array}{l}0.02 * * * \\
(0.00)\end{array}$ & $\begin{array}{l}0.02^{* * * *} \\
(0.00)\end{array}$ & $\begin{array}{l}0.02^{* * * *} \\
(0.00)\end{array}$ & $\begin{array}{l}0.02^{* * * *} \\
(0.00)\end{array}$ \\
\hline Per cent of same income group that ratified & $\begin{array}{c}-0.00 \\
(0.00)\end{array}$ & $\begin{array}{c}0.00 \\
(0.00)\end{array}$ & $\begin{array}{c}0.00 \\
(0.00)\end{array}$ & $\begin{array}{c}0.00 \\
(0.00)\end{array}$ & $\begin{array}{c}-0.00 \\
(0.00)\end{array}$ \\
\hline Per cent of countries in region that ratified & $\begin{array}{l}0.03^{* * * *} \\
(0.00)\end{array}$ & $\begin{array}{l}0.03 * * * \\
(0.00)\end{array}$ & $\begin{array}{l}0.03^{* * *} \\
(0.00)\end{array}$ & $\begin{array}{l}0.03 * * * \\
(0.00)\end{array}$ & $\begin{array}{l}0.03^{* * *} * \\
(0.00)\end{array}$ \\
\hline Democracy (Polity) & $\begin{array}{l}0.02 * * * \\
(0.01)\end{array}$ & $\begin{array}{l}0.01 * \\
(0.01)\end{array}$ & - & - & $\begin{array}{l}0.01 * \\
(0.01)\end{array}$ \\
\hline Political rights & - & - & $\begin{array}{c}-0.07 * * \\
(0.03)\end{array}$ & - & - \\
\hline Civil liberites & - & - & $\begin{array}{l}0.18^{* * * *} \\
(0.04)\end{array}$ & - & - \\
\hline Mean of civil lib. + political rights & - & - & - & $\begin{array}{l}0.07 * * * \\
(0.02)\end{array}$ & - \\
\hline ln GDP p.c. & $\begin{array}{c}1.04 * \\
(0.58)\end{array}$ & $\begin{array}{c}0.93 \\
(0.62)\end{array}$ & $\begin{array}{l}1.07 * * \\
(0.54)\end{array}$ & $\begin{array}{c}0.89 \\
(0.57)\end{array}$ & $\begin{array}{c}0.71 \\
(0.62)\end{array}$ \\
\hline $\ln$ GDP p.c. ${ }^{2}$ & $\begin{array}{c}-0.04 \\
(0.04)\end{array}$ & $\begin{array}{c}-0.04 \\
(0.04)\end{array}$ & $\begin{array}{c}-0.05^{*} \\
(0.03)\end{array}$ & $\begin{array}{c}-0.04 \\
(0.03)\end{array}$ & $\begin{array}{c}-0.02 \\
(0.04)\end{array}$ \\
\hline $\ln \mathrm{SO}_{2}$ p.c. & $\begin{array}{l}0.12 * * * \\
(0.03)\end{array}$ & $\begin{array}{l}0.09 * * * \\
(0.03)\end{array}$ & $\begin{array}{l}0.09 * * * \\
(0.03)\end{array}$ & $\begin{array}{l}0.09 * * * \\
(0.03)\end{array}$ & $\begin{array}{l}0.09 * * * \\
(0.03)\end{array}$ \\
\hline $\ln$ GDP & $\begin{array}{c}-0.10^{*} \\
(0.06)\end{array}$ & $\begin{array}{c}-0.07 \\
(0.07)\end{array}$ & $\begin{array}{c}0.02 \\
(0.07)\end{array}$ & $\begin{array}{c}-0.01 \\
(0.07)\end{array}$ & $\begin{array}{c}-0.06 \\
(0.07)\end{array}$ \\
\hline Africa & - & $\begin{array}{c}-0.51 * * * \\
(0.15)\end{array}$ & $\begin{array}{c}-0.44 * * * \\
(0.14)\end{array}$ & $\begin{array}{c}-0.43 * * * \\
(0.14)\end{array}$ & $\begin{array}{c}-0.48^{* * * *} \\
(0.15)\end{array}$ \\
\hline North America & - & $\begin{array}{c}-0.55^{* * * *} \\
(0.16)\end{array}$ & $\begin{array}{c}-0.73 * * * \\
(0.21)\end{array}$ & $\begin{array}{c}-0.67 * * * \\
(0.20)\end{array}$ & $\begin{array}{c}-0.59 * * * \\
(0.15)\end{array}$ \\
\hline Latin America & - & $\begin{array}{c}-0.54 * * * \\
(0.12)\end{array}$ & $\begin{array}{c}-0.49 * * * \\
(0.12)\end{array}$ & $\begin{array}{c}-0.49 * * * \\
(0.12)\end{array}$ & $\begin{array}{c}-0.53^{* * * *} \\
(0.12)\end{array}$ \\
\hline East Asia & - & $\begin{array}{c}-0.46^{* * * *} \\
(0.14)\end{array}$ & $\begin{array}{c}-0.50 * * * \\
(0.14)\end{array}$ & $\begin{array}{c}-0.48 * * * \\
(0.15)\end{array}$ & $\begin{array}{c}-0.46^{* * *} \\
(0.14)\end{array}$ \\
\hline West Asia & - & $\begin{array}{c}-0.71^{* * *} \\
(0.16)\end{array}$ & $\begin{array}{c}-0.61 * * * \\
(0.15)\end{array}$ & $\begin{array}{c}-0.63^{* * *} \\
(0.16)\end{array}$ & $\begin{array}{c}-0.71^{* * * *} \\
(0.16)\end{array}$ \\
\hline United Kingdom & - & - & - & - & $\begin{array}{l}0.17^{* * * *} \\
(0.06)\end{array}$ \\
\hline United States & - & - & - & - & $\begin{array}{l}0.20^{* * * *} \\
(0.06)\end{array}$ \\
\hline Germany & - & - & - & - & $\begin{array}{l}0.14^{* *} \\
(0.06)\end{array}$ \\
\hline Spain & - & - & - & - & $\begin{array}{l}0.22^{*} \\
(0.06)\end{array}$ \\
\hline France & - & - & - & - & $\begin{array}{c}0.10 \\
(0.06)\end{array}$ \\
\hline Russia & - & - & - & - & $\begin{array}{c}0.08 \\
(0.06)\end{array}$ \\
\hline Brazil & - & - & - & - & $\begin{array}{c}-0.08 \\
(0.07)\end{array}$ \\
\hline China & - & - & - & - & $\begin{array}{l}0.29^{* * *} \\
(0.09)\end{array}$ \\
\hline India & - & - & - & - & $\begin{array}{l}0.31^{* * *} \\
(0.06)\end{array}$ \\
\hline$t$ & $\begin{array}{c}-0.33 * * * \\
(0.02)\end{array}$ & $\begin{array}{c}-0.33 * * * \\
(0.02)\end{array}$ & $\begin{array}{c}-0.31 * * * \\
(0.02)\end{array}$ & $\begin{array}{c}-0.31 * * * \\
(0.02)\end{array}$ & $\begin{array}{c}-0.38^{* * *} \\
(0.02)\end{array}$ \\
\hline
\end{tabular}


TABLE 3 (Continued)

\begin{tabular}{|c|c|c|c|c|c|}
\hline & (1) & (2) & (3) & (4) & (5) \\
\hline$t^{2}$ & $0.01 * * *$ & $0.01 * * *$ & $0.01 * * *$ & $0.01 * * *$ & $0.01 * * *$ \\
\hline & $(0.00)$ & $(0.00)$ & $(0.00)$ & $(0.00)$ & $(0.00)$ \\
\hline$t^{3}$ & $\begin{array}{c}-0.00 * * * \\
(0.00)\end{array}$ & $\begin{array}{l}-0.00 * * * \\
(0.00)\end{array}$ & $\begin{array}{l}-0.00 * * * \\
(0.00)\end{array}$ & $\begin{array}{c}-0.00 * * * \\
(0.00)\end{array}$ & $\begin{array}{c}-0.00^{* * * *} \\
(0.00)\end{array}$ \\
\hline Constant & $\begin{array}{l}-9.92^{* * * *} \\
(2.55)\end{array}$ & $\begin{array}{l}-9.39 * * * \\
(2.97)\end{array}$ & $\begin{array}{c}-11.34^{* * * *} \\
(2.50)\end{array}$ & $\begin{array}{c}-10.28 * * * \\
(2.64)\end{array}$ & $\begin{array}{l}-8.98 * * * \\
(2.96)\end{array}$ \\
\hline Observations & 574,196 & 574,196 & 574,547 & 574,547 & 574,196 \\
\hline
\end{tabular}

Note: Robust standard errors in parentheses.

$* * * p<0.01, * * p<0.05, * p<0.1$.

positive, and trade has a statistically significant negative, effect on ratification behaviour. As to the hypothesized contingent behaviour effects, our results show that the number of countries that previously ratified a given treaty significantly increases the likelihood that any other country will also ratify that treaty (Hypothesis 3a). The same holds true for the share of countries in a given country's region that previously ratified the treaty (Hypothesis $3 \mathrm{~b}$ ). In contrast, the share of countries in a given country's income group that previously ratified the treaty has no statistically significant effect (Hypothesis 3c). The latter result suggests that geographically defined contingency effects are stronger than income-related contingency effects. Except for the number of countries per income group, all unit-external variables are therefore significantly related to the likelihood of treaty ratification.

This is also the case when we turn to the internal effects. Both democracy and income affect countries' ratification behaviour positively. To visualize the non-linear effect of income, Figure 1 shows the effect of the log of GDP per capita and its squared term on the likelihood of treaty ratification while all other variables are kept at their mean levels. ${ }^{89}$ It indicates that countries with a higher GDP per capita are more likely to ratify international environmental treaties, but it also shows that the overall effect of GDP per capita is rather small.

As to the control variables, power has a negative effect. That is, the more powerful a country is - measured in terms of GDP - the less likely it is to ratify a treaty. Thus, more powerful countries, rather than trying to become environmental role models, appear to be able to get away with less co-operative behaviour. The negative effect persists when we use population instead of GDP to measure a country's power.

The effect of the domestic environmental quality variable, proxied by $\mathrm{SO}_{2}$ emissions per capita, is positive and significant: the higher the $\mathrm{SO}_{2}$ emissions per capita, the more likely a country is to ratify global environmental agreements. This result should be interpreted with caution because the proxy we use is a very crude one. Nonetheless, there are two potential interpretations that could be examined in more detail in future research. One is that governments of countries exposed to greater environmental damage use global environmental agreements to tie their hands vis-à-vis opposing domestic constituencies. The other is that governments of such countries use global environmental agreements

\footnotetext{
${ }^{89}$ A more intuitive illustration is provided in the web appendix by a similar figure using GDP per capita instead of the log of GDP per capita.
} 


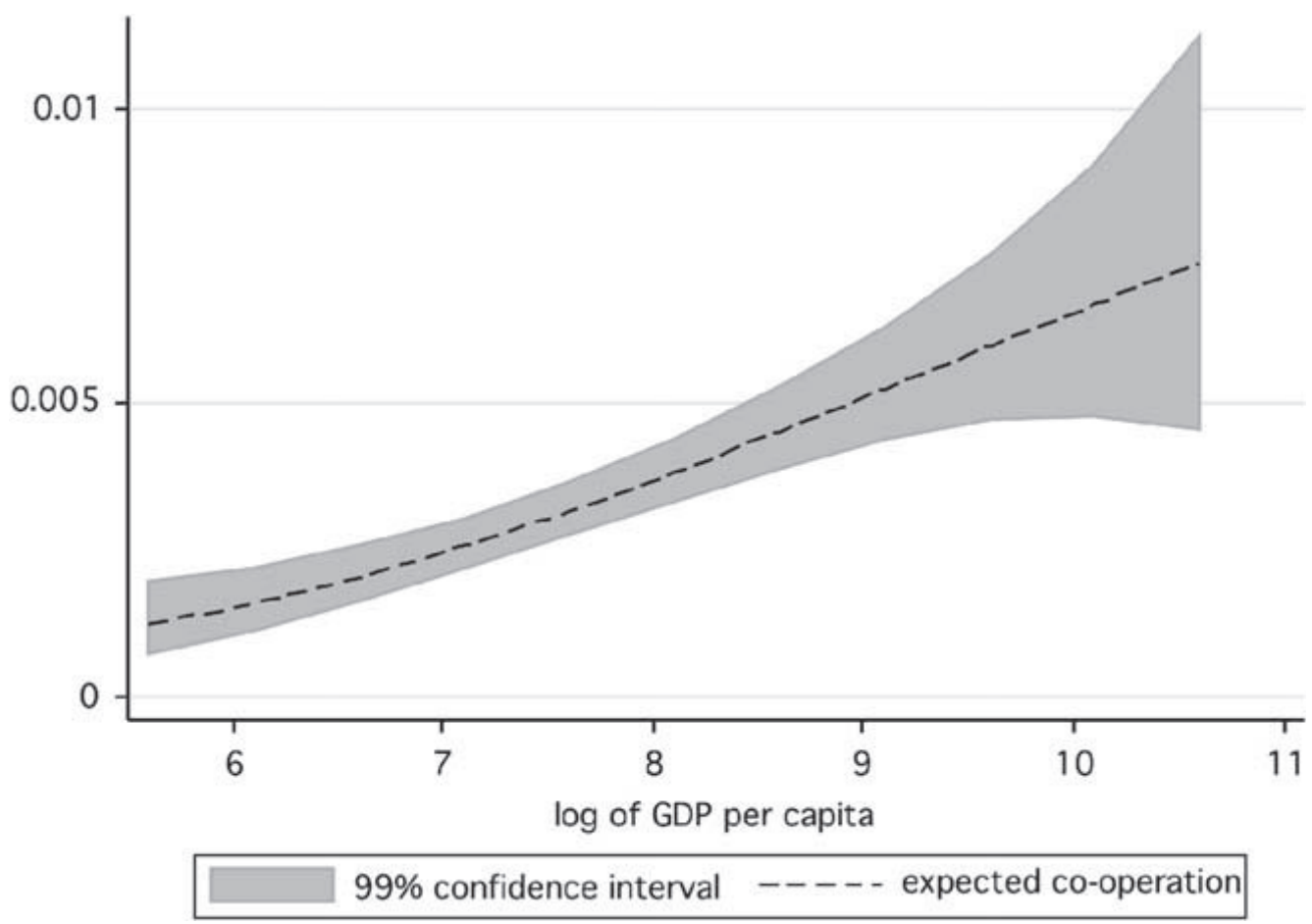

Fig. 1. Effect of $\log$ GDP per capita on the likelihood of treaty ratification Note: All other variables are kept at their means.

to purchase international goodwill and improve their reputation, particularly if their environmental behaviour generates transboundary externalities (which is often the case with $\mathrm{SO}_{2}$ emissions).

In column 2 of Table 3, the principal model is extended to include regional dummy variables. Compared to the base category, which is Europe, countries located in any of the other regions are less likely to ratify global environmental treaties, as indicated by the negative and statistically significant coefficients. In columns 3 and 4 of Table 3 , we evaluate the effect of democracy in more detail. When we use the civil and political rights variables from Freedom House (column 3), we obtain a different picture from the one shown in column 1 in which we used the Polity IV index to measure democracy. We observe that more civil liberties increase the probability of joining a global treaty. In contrast to the results in column 1, more political rights decrease a country's propensity to ratify. When both civil and political rights are combined into one variable, the positive effect prevails (column 4 in Table 3). ${ }^{90}$ These results suggest that, in sum, democracies tend to be more willing to join international environmental treaties. However, the effect appears to be mostly due to the demand side of the political system as civil liberties allow citizens to pressure their governments to behave more cooperatively at the international level. The supply side of democracies, the political rights, does not seem to promote

90 Although political rights and civil liberties, as measured by Freedom House, are highly correlated, they capture distinct phenomena. For example, some countries score lower on civil rights than on political rights (e.g. Italy, Argentina and Colombia) and others score higher on civil liberties than on political rights (e.g. Peru and Brazil). In any event, high correlation between the two variables does not cast doubt on our findings because multicollinearity does not bias coefficients. It only increases standard errors, which make it harder to obtain statistically significant results. 
international environmental co-operation. This result is in line with the results of studies that find positive effects of civil society pressure (which can be regarded as a demand side indicator) on environmental treaty ratifications. ${ }^{91}$

The last column in Table 3 shows the results of a model that includes dummy variables indicating whether important countries (in terms of economic size and/or population) have already ratified a given treaty. It indicates that prior ratification by countries such as China, Germany and Britain has a positive effect. The effect is most pronounced for India, and least important and indeed insignificant for France, Russia and Brazil. ${ }^{92}$ In other words, our results show that powerful countries are less likely to ratify, but once they do so, this motivates other countries to join as well.

The statistical approach used in this article also allows us to obtain an estimate of time dependence underlying treaty ratification behaviour in our sample. ${ }^{93}$ Figure 2 indicates the likelihood of treaty ratification as a function of $t, t^{2}$ and $t^{3}$ while all other variables are kept at their mean levels. The figure shows that the baseline hazard decreases strongly with time. That is, the probability of ratification by any given country is higher shortly after a treaty is opened for ratification and then decreases over time.

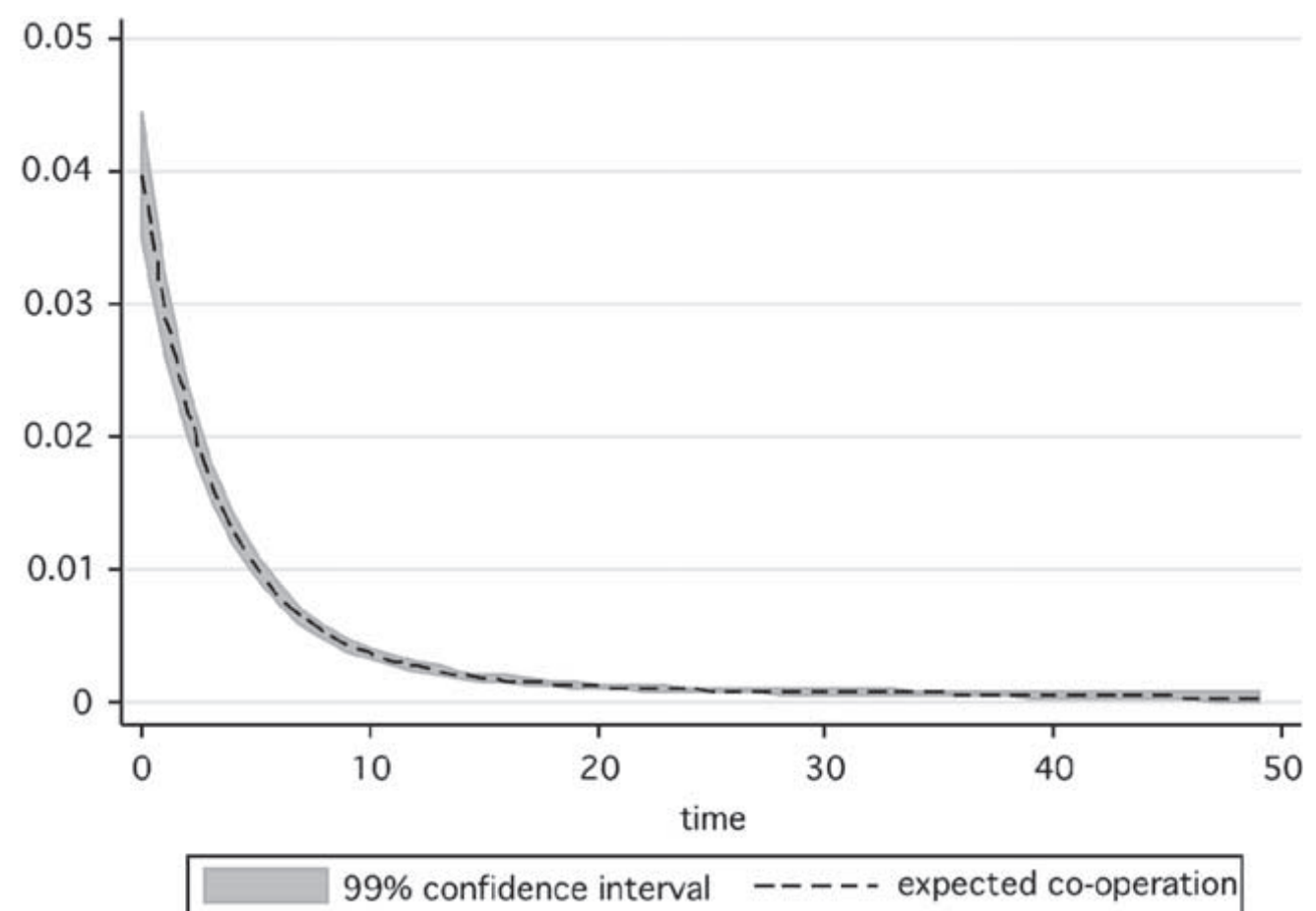

Fig. 2. Likelihood of treaty ratification over time

Note: All other variables are kept at their means.

${ }^{91}$ See, for example, Roberts et al., 'Who Ratifies Environmental Treaties and Why?' Frank, 'The Social Bases of Environmental Treaty Ratification, 1900-1990'.

${ }_{92}$ We also tested the effect of ratification by important countries with a dummy variable indicating whether the particular country is a major power (based on the Correlates of War data). This variable has no significant effects in our models - see web appendix.

${ }_{93}$ Using a likelihood ratio test, we examined whether there is time dependence in our model. The test clearly rejected the model without $t, t^{2}, t^{3}\left(\mathrm{LR} \mathrm{chi}^{2}(3)=7977.55\right.$; Prob $\left.>\operatorname{chi}^{2}=0.00\right)$. 
TABLE 4 Simulated Probabilities, Principal Model

\begin{tabular}{lccc}
\hline \hline Simulated Probability Pr(ratification = 1) & Mean to Max & Min to Mean & Min to Max \\
\hline IO membership & 0.007 & 0.002 & 0.009 \\
& $(0.003)$ & $(0.000)$ & $(0.003)$ \\
In trade intensity & -0.001 & -0.004 & -0.006 \\
& $(0.000)$ & $(0.003)$ & $(0.003)$ \\
Number of other countries that ratified & 0.136 & 0.001 & 0.137 \\
& $(0.053)$ & $(0.000)$ & $(0.053)$ \\
Per cent of same income group that ratified & -0.001 & -0.000 & -0.001 \\
& $(0.001)$ & $(0.000)$ & $(0.001)$ \\
Per cent of countries in region that ratified & 0.080 & 0.001 & 0.081 \\
Democracy (Polity) & $(0.017)$ & $(0.000)$ & $(0.017)$ \\
& 0.001 & 0.001 & 0.002 \\
& $(0.000)$ & $(0.000)$ & $(0.001)$ \\
\hline \hline
\end{tabular}

Note: Standard errors in parentheses; all other variables are kept at their mean values.

To obtain a better intuition of the estimated relationships between our main independent variables and the propensity of treaty ratification we simulated predicted probabilities. ${ }^{94}$ The results are shown in Table $4 .{ }^{95}$ They are based on the principal model shown in column 1 , Table 3. The predicted probabilities displayed in Table 4 clearly indicate that the effects of international factors are stronger than the effects of domestic factors. It should be noted in this context that the size of the effects we compare is independent of potential multicollinearity between domestic variables.

The first column of Table 4 shows changes in probabilities of treaty ratification if the explanatory variable concerned changes its value from the mean to the maximum. Columns 2 and 3 indicate changes in the propensity of treaty ratification for changes of the explanatory variable from the minimum to the mean and from the minimum to the maximum. Interestingly, the effects of the contingent behaviour variables, except for the ratification share in the same income group, are much stronger than the effects of democracy and income. ${ }^{96}$ For example, a change from full autocracy (Polity IV value of -10 ) to full democracy (Polity IV value of +10 ) increases the probability of ratification by 0.2 per cent. In contrast, if the share of ratifiers in a country's region changes from the mean to the maximum, this increases the probability of ratification by 8 per cent. Similarly, a change from the mean number of IO memberships, which is 50 , to the maximum number of 134 produces an increase in the ratification probability by 0.7 per cent.

${ }^{94}$ The simulation results were obtained using CLARIFY (Michael Tomz, Jason Wittenberg and Gary King, 'CLARIFY: Software for Interpreting and Presenting Statistical Results', Version 2.0 (Cambridge, Mass.: Harvard University, 1 June 2001), see http://gking.harvard.edu; Gary King, Michael Tomz and Jason Wittenberg, 'Making the Most of Statistical Analyses: Improving Interpretation and Presentation', American Journal of Political Science, 44 (2000), 347-61).

${ }^{95}$ To further illustrate the effects of our main independent variables, we have created graphs that plot the likelihood of treaty ratification over the whole range of the independent variable in question while all other variables are kept at their mean values. These figures can be found in the web appendix.

${ }^{96}$ Since we include both GDP per capita and its square as terms in the regression, we use Figure 1 to illustrate the overall effect of GDP per capita on treaty ratification. From this figure, we can deduce that the change in probabilities from the minimum to the maximum level of GDP per capita is smaller than for the contingent behaviour variables such as the number of other countries that have ratified the treaty. 
Furthermore, Table 4 shows that, except for trade intensity, all effects are stronger when the explanatory variable changes from its mean to its maximum value compared to a change from its minimum to its mean value. This indicates that there are potential threshold effects: if only some countries in a region have ratified a given treaty, the likelihood of another country in this region ratifying this treaty does not increase much. However, if a larger number of countries in a region have already ratified, the likelihood of ratification for the remaining countries in this region increases quite strongly.

To illustrate what our results imply 'in reality', we calculated predicted probabilities for specific country characteristics, using the United States, China, Switzerland, Morocco and Costa Rica as examples. All country-specific variables such as trade or democracy were set to the value the particular variable took in the year 2000 for the respective country. All treaty-specific variables such as the number of countries that had already ratified the treaty were set to their mean values. Table 5 shows the predicted probabilities as well as the values for which they were calculated. For example, the probability that the United States ratifies any given treaty based on its trade, democracy score, IO membership, air pollution and income in the year 2000 turns out to be 1.4 per cent. This probability is somewhat higher compared to Switzerland for which the probability of treaty ratification is predicted to be 0.8 per cent, and much higher compared to China, Morocco, and Costa Rica for which the probability is predicted to be 0.5 per cent.

In absolute terms, the probabilities shown in Tables 4 and 5 appear to be very small. But it needs to be borne in mind that treaty ratifications are rare events (only 0.88 per cent of all observations are coded as 1), so that probabilities of treaty ratification estimated by any statistical model are automatically very small. In other words, the effects of IO membership and the contingent behaviour variables, which are proxies for linkages of countries with their external environment, are in fact very substantial.

\section{Robustness Checks}

We have checked the robustness of our results in various ways. For a start, we have examined whether particular specifications of the main explanatory variables affect the results. Various measures for IO membership, democracy, power and trade are used to that end. To assess whether our results are sensitive to the estimation method, we re-estimated the model using different econometric approaches, checked whether the fact that ratification is a rare event influences the main results, accounted for right-censoring, and controlled for potential unit heterogeneity in various ways. We have also evaluated whether the inclusion of additional control variables changes the results. Furthermore, we have used different definitions of what is to be considered a global environmental treaty and re-estimated the principal model for the resulting samples. Finally, we revisited the results for the trade variable to examine whether they might be disproportionately influenced by those countries that trade intensively or only very little. Our main results are robust to all these alterations (the results of all robustness checks are presented in the web appendix).

\section{CONCLUSION}

In this article, we have examined the extent to which linkages of countries with their external environment (external factors) affect global governance dynamics, relative to domestic level determinants (internal factors). We conceptualized such linkages in terms of a country's involvement in international organizations of any type, its integration into the world economy, and contingent behaviour. The empirical focus is on global environmental co-operation. 


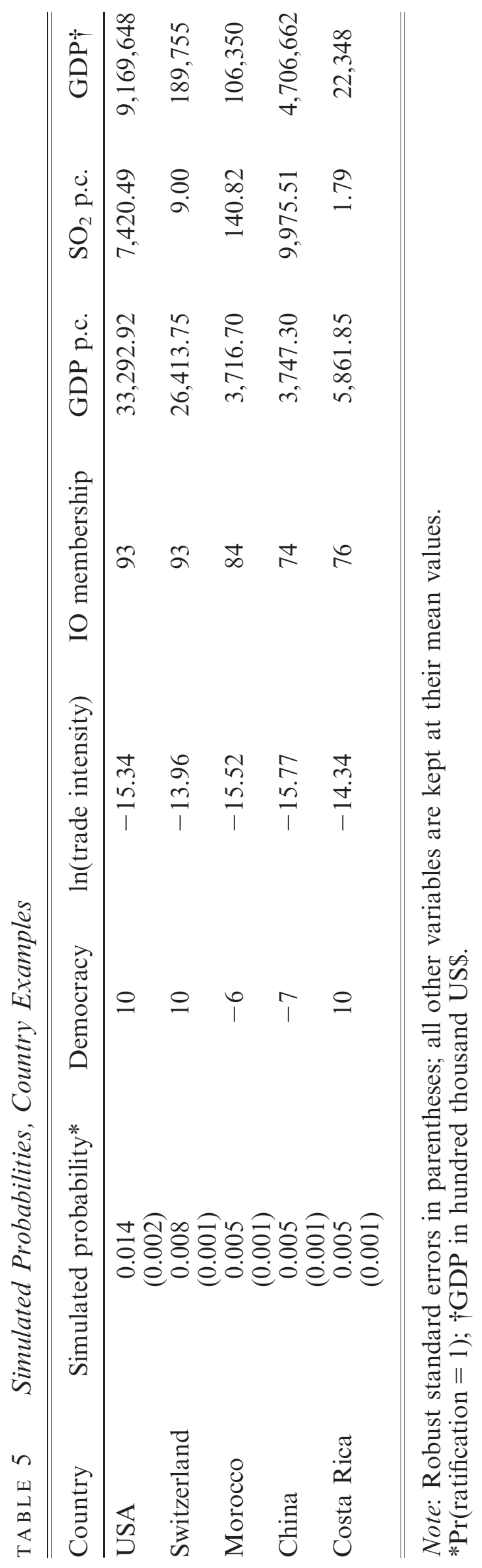


We hypothesized that involvement in international organizations and contingency variables have a positive effect on global environmental co-operation, and that economic integration into the world economy has a negative effect. Empirical testing was performed on a sample of 180 countries and approximately 255 multilateral environmental treaties over fifty years (1950-2000). The most important empirical finding is that, overall, international factors have a stronger effect on co-operative behaviour (in the form of treaty ratification) than domestic factors, such as income and democracy.

The main implication of our findings for research on international co-operation and institutions is that linkages of states with their external environment should receive greater attention, both at the theoretical and empirical levels. Explanatory models of cooperative behaviour of states in the international realm have become increasingly sophisticated in specifying the domestic drivers of such behaviour. But they have paid rather little attention to the fact that international co-operation is a complex process in which any given country's behaviour is also shaped by the extent to which it is embedded in the international system, and by how specific other countries behave. Our results demonstrate that explanatory models of international co-operation that ignore international linkages may be misspecified. This conclusion, in general terms, is very much in line with conclusions that have recently emerged from the literature on policy-diffusion and international networks. ${ }^{97}$

The empirical results reported in this article are based on the analysis of global environmental governance efforts. We are quite confident, however, that the analysis of international co-operative behaviour (as indicated by treaty ratifications) in other policy areas is likely to produce similar findings. Our empirical approach may serve as a useful template for such research. Further research could also move beyond the rather simple IO membership variable and focus on more sophisticated indicators for the position of countries in international political/institutional networks. ${ }^{98}$ And it could include more detailed control variables pertaining to treaty characteristics.

The main policy implication is that the existing literature may be too optimistic about the co-operation-promoting effects of wealth, democracy and trade. Countries' decisions on whether or not to participate in global governance efforts may be influenced in larger measure by their general involvement in international organizations of any type, and by what other countries do in the same policy area. This conclusion is in fact quite encouraging. It implies that there is considerable room for proactive policies that promote global governance efforts. Our results show that countries interested in the effective formation of global governance systems can positively influence laggard country behaviour by moving ahead with ratification. They also suggest that 'entangling' reticent countries in more international organizations of any type can be helpful in promoting the formation of specific global governance systems.

97 Ward, 'International Linkages and Environmental Sustainability'; Dietmar Braun and Fabrizio Gilardi, 'Taking “Galton's Problem” Seriously', Journal of Theoretical Politics, 18 (2006), 298-322; Han Dorussen and Hugh Ward, 'Intergovernmental Organizations and the Kantian Peace: A Network Perspective', Journal of Conflict Resolution, 52 (2008), 189-212; Charles Shipan and Craig Volden, 'The Mechanisms of Policy Diffusion', American Journal of Political Science, 52 (2008), 840-57.

98 Ward, 'International Linkages and Environmental Sustainability'. 